\title{
Archaeological Survey and Testing at Rancho de las Cabras, Wilson County, Texas
}

James E. Ivey

Anne A. Fox

Follow this and additional works at: https://scholarworks.sfasu.edu/ita

Part of the American Material Culture Commons, Archaeological Anthropology Commons, Environmental Studies Commons, Other American Studies Commons, Other Arts and Humanities Commons, Other History of Art, Architecture, and Archaeology Commons, and the United States History Commons

Tell us how this article helped you.

This Article is brought to you for free and open access by the Center for Regional Heritage Research at SFA ScholarWorks. It has been accepted for inclusion in Index of Texas Archaeology: Open Access Gray Literature from the Lone Star State by an authorized editor of SFA ScholarWorks. For more information, please contact cdsscholarworks@sfasu.edu. 


\section{Archaeological Survey and Testing at Rancho de las Cabras, Wilson County,}

Texas

\section{Creative Commons License}

(c) (1) (2)

This work is licensed under a Creative Commons Attribution-NonCommercial 4.0 International License 


\title{
ARCHAEOLOGICAL SURVEY AND TESTING AT RANCHO DE LAS CABRAS, WILSON COUNTY, TEXAS
}

\author{
JAMES E. IVEY AND ANNE A. FOX
}





\title{
ARCHAEOLOGICAL SURVEY AND TESTING \\ AT RANCHO DE LAS CABRAS, WILSON COUNTY, TEXAS
}

\author{
James E. Ivey \\ and \\ Anne A. Fox
}

Center for Archaeological Research

The University of Texas at San Antonio

Archaeological Survey Report, No. 104 
The following information is provided in accordance with General Rule of Practice and Procedure 355.01.011C. Texas Antiquities Committee:

1. Historical, architectural and archaeological investigations at the Rancho de las Cabras;

2. Rancho de las Cabras;

3. Wilson County, Texas;

4. Thomas R. Hester and Jack..D. Eaton, Principal Investigators; Anne A. Fox, Project Director;

5. Texas Parks and Wildlife Department;

6. Texas Historical Commission Antiquities Permit No. 280;

7. Published by the Center for Archaeological Research, The University of Texas at San San Antonio, San Antonio, Texas 78285; June 1981. 


\section{ABSTRACT}

During summer 1980 a program of archaeological survey and testing was carried out by the Center for Archaeological Research, The University of Texas at San Antonio, for the Texas Parks and Wildlife Department at the site of Rancho de las Cabras near Floresville, Texas. The site is reputed to be the livestock ranch of Mission San Francisco de la Espada in the late 18th century: Large areas of the site were surveyed to determine if prehistoric sites were present. The limits of the historic occupation were determined through surface survey and shovel testing. Archaeological testing within and adjacent to the historic ruins located architectural and cultural features which will need further excavation and study. The depth and composition of the historic deposits throughout the site were tested and recorded. A map of the compound was prepared in cooperation with professional surveyors provided by the Parks and Wildlife Department. Recommendations for future historical and archaeological research are included in the report. 
TABLE OF CONTENTS

Page

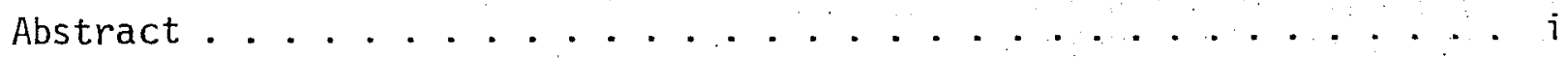

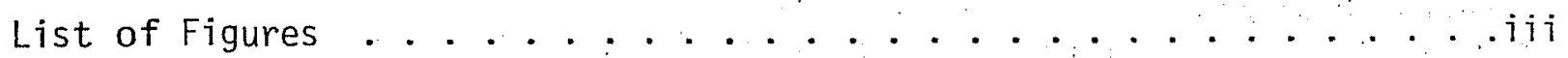

List of Tables............................ i i

Acknowledgments ......................... iv

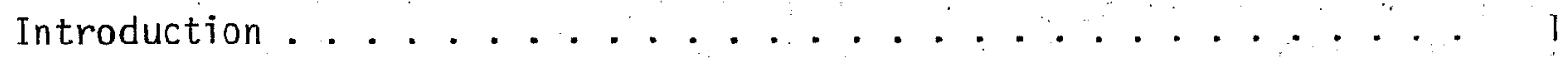

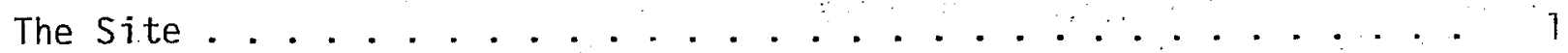

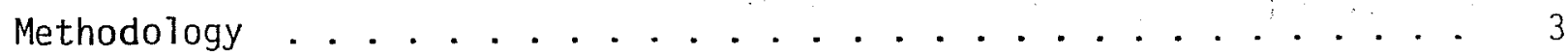

The Investigations . . . . . . . . . . . . 5

Surface Surveys .................... 5

Surface Collection ................. 7

Shovel Tests...................... 7

Test Excavation Units ................ . . 7

The Artifacts .................. 30

The Spanish Occupation................ 31

19th and 20th Century Artifacts ............. 40

The Temporal Range of Site Occupation ........... 40

Conclusions ....................... 40 40

Structura 1 History ............... . . 40

Historical Context ............... . 42

Life in the Compound............... 43

Recommendations ............... . . 45

References cited ................ 46 


\section{LIST OF FIGURES}

Figure

Page

1. Locationat Map of Rancho de las Cabras . . . . . . . . 2

2. Map of the Site .................... 6

3. Profile of Units 2 and 3.................... 13

4. Profile of Unit 4 ........................... 17

5. Profile of Unit 8 ....................... 21

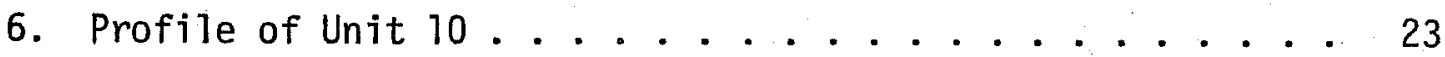

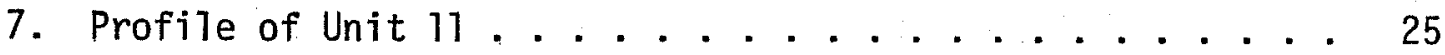

8. Ceramics From Rancho de Tas Cabras . . . . . . . . . 33

9. Artifacts From Rancho de las Cabras ............. 38

\section{LIST OF TABLES}

Table

1. Provenience of Artifacts from 1980 Excavations . . . . . . 8

2. Vertebrate. Fauna Recovered from Las Cabras... . . . . . . 39 


\section{ACKNOWLEDGMENTS}

The successful completion of this first phase of the work at Rancho de las Cabras could not have been accomplished without the help and cooperation of numerous people. We are grateful to J. David Ing, Orion Knox, Sue Moss, and Sheron SmithSavage of the Texas Parks and Wildlife Department for their enthusiastic support during the project. Surveyor Rick Wilkinson and his aides were most efficient and cooperative during the mapping operation.

We also wish to thank particularly Mr. and Mrs. Winston Southern for their help in obtaining access to the property and their personat interest in our work. Jack J. Bruce spent many hours providing background information and maps of the surrounding countryside. Jim Hickey, Waynne Cox, and Rebekah Halpern provided volunteer excavation services. Our thanks also go to Chairman Roy $L$. Swift, Winston Davis, and the other members of the Wilson County Historical Commission who made us feel welcome and provided early photographs and eyewitness descriptions of the site. County Judge W. D. Cox was also most supportive of the project. The librarians in the Floresville Public Library were gracious, helpful, and patient with our persistent questions. Our stay in Floresville was made pleasant by the hospitable attitude of everyone with whom we came in contact. 
In July 1980, the Center for Archaeological Research, The University of Texas at San Antonio, carried out preliminary survey and test excavations at the site of Rancho de las Cabras on the San Antonio River just south of Floresville, Texas (Fig. 1). The contract called for the following activities:

(1) an intensive survey of the proposed entrance road, 100 feet wide (see Fig. 1);

(2) an intensive survey of the "Southern" tract, with shovel testing where necessary to delimit the historic site deposits;

(3) archaeological testing north-northwest of the rancho compound to delineate the archaeologically sensitive zone and to determine the location of culturally sterile areas which could be used for support facilities. This will include patterned shovel testing and $1-m^{2}$ excavation units where necessary;

(4) archaeological testing in and immediately around the rancho compound to determine the nature and extent of cultural deposits;

(5) cooperation with a professional surveyor provided by the Texas Parks and Wildlife Department in establishing permanent grid markers and making a topographic map of the rancho compound and related features;

(6) production of a scientific report of the results of the investigations.

The materials recovered and all maps, notes, and records will be stored at the Center for Archaeological Research Laboratory, The University of Texas at San Antonio.

\section{THE SITE}

Rancho de las Cabras is the site of the livestock ranching operations which reputedly was begun in connection with the mission San Francisco de la Espada in the mid-18th century. The mission was founded on the San Antonio River south of the town of San Antonio de Bexar in 1731. Comparatively little research has been done on Mission Espada, and hardly any information on the ranch thus far has been found. This project was intended to make some basic determinations about the nature of the site itself, to be used in planning further excavations, and to assist in planning future development of the park to be located there. Additional excavations will be done to answer specific questions formulated during this preliminary investigation.

The site is located on a high point of land which overlooks the San Antonio River valley to the east, and for some distance along the river to the north and south. Sandstone block walls up to five and six feet high still remain along the north edge of what was apparently an irregularly-shaped walled compound. The rolling countryside around the site is shaped by arroyos which drain into the river about 
This page has been

redacted because it

contains restricted

information. 
two kilometers to the east of the ruins and Picosa Creek to the northeast. The Southern tract portion of the land acquired by the Parks and Wildlife Department from Winston Southern consists of ca. 55.5 acres of upland which contain the ruins at the southern end, and an area to the north which is apparently free of historical remains and could be used for development of visitor facilities.

The soil is a gray brown sandy clay loam over a yellow brown clay loam subsoil. Upland areas, where they have not been cleared for pasture, are overgrown with mesquite and thorny brush. Live oak, post oak, and pecan are present in the arroyos and river bottom areas. The fields around the ruins have, in recent years, been completely cleared of brush and used for pasture by the former owner, who carefully left the ruins and an area immediately around them untouched.

The existence and location of Las Cabras have been known to the local people and to a few historians and archaeologists for many years, and a body of local stories has accumulated about the site and its former occupants. The spot has been visited numerous times by hunters and fishermen traveling the river valley, and by local Floresville citizens who 7iked to visit the spot in the late 19th and early 20th centuries. A number of deep disturbances along the north wal1 reflect the insatiable turn-of-the-century gold hunting fever which also left the San Antonio missions pockmarked and crumbling by 1930. Stone blocks from the walls were, for many years, carried away to build walls and other architectural features in and around the town of Floresville. Stone monuments which once marked the limits of the town, built of Las Cabras stones, have been carried back to the site and dumped with the walls (Jack Bruce, personal communication). The sight of stones set in contemporary cement mortar which match those in the 18th century structures are a bit startling to the archaeologist, until their origin is explained.

Despite the above described intrusions, the site of Rancho de las Cabras is remarkably well preserved and, as can be seen from this report, contains tremendous potential for years of historical, archaeological, and ethnographic research.

\section{METHODOLOGY}

The field work was carried out from late June 1980 to the end of July 1980. Anne Fox was Project Director. The crew consisted of James Ivey (Field Director), Lois Flynn, Augustine Frkuska, and Roberta McGregor. Principal Investigators for the project were Thomas R. Hester, Director, and Jack D. Eaton, Associate Director, of the Center for Archaeological Research.

The scope of the contract was designed to answer a specific set of questions. Since virtually nothing was known about the archaeology of the site or its environs, no effective planning of future archaeological work could be done. At the same time, very little was known about the history of the site, a difficulty for which archaeology could offer some help.

The primary emphasis, however, was on the determination of the nature and extent of the cultural deposits. Work was done to determine the amount of overburden, (if any); the thickness and depth of cultural deposits throughout the site; and what sort of architectural features could be expected in terms of wall and floor material. It was important to find the location of the refuse from day-to-day life at the site, and whether the actual zone of occupation extended outside the 
wall 1 ines of the structures. Equally important, Texas Parks and Wildlife wanted to know if certain areas of the property were without cultural deposits, either historic or prehistoric, so that such areas could be used for the access road and visitors' center with minimum disturbance to the cultural resources of the area.

In practice, while excavating within the structural ruins, several basic rules were followed. The first and most important was to minimize disturbance. Small units in the range of $1-m^{2}$ to $2-m^{2}$, used as isolated tests, are insufficient in size to deal effectively with the remains of a large structure, especially one which might have several periods of occupation and contain several types of construction. The urge to put in another unit to find out where a wall is going or to locate the other edge of a pit is frequently tempting, but consumes time. Units of a specific size were opened and, regardless of what was found, were not enlarged. Units were so placed as to answer the questions defined by the contract as their first purpose, and to supply some answers to more specific questions about the distribution of structures within the site secondarily.

The second rule was to answer the questions proposed by the contract. New questions about the site would be noted, but no attempt was made to find the answers outside the test units. When a feature such as an unsuspected wall, trash pit, gateway, or floor was located, its position was plotted and a note made to include it in recommended future work.

Areas of major structural debris were avoided where possible. Problems such as the clearing and excavation of probable bastion locations were left for more specific contracts. The moving of a large volume of debris would not be an effective use of our limited field time, and would be an attempt to find an answer rather than to define the problem.

With these considerations in mind, a coordinate grid was established and a series of units selected. The grid was set up as indicated in Figure 1, with an arbitrary grid north at right angles to the longest face of the compound wall, on the true northwest side. The south face of the (grid) north wall was designated as the line determining the orientation of the coordinate system, and was defined as being 105 meters south of the zero-point of the coordinates.

The reasoning behind the selection of the position of each unit will be presented in the next section, along with the other pertinent information about the unit.

Units were excavated by natural strata. Control was maintained by measurements of selected thicknesses of strata as the excavation proceeded. Section drawings were then made, and the stratum as an excavation unit was indicated on the section.

Al1 excavated material was screened through 1/4-inch hardware cloth. Recovered artifacts were collected in sacks on which were recorded the name and number of the site, the unit and stratum, the date, the names of the excavators, and any remark, sketch, or other information considered necessary to insure that the point of origin of the enclosed artifacts could be determined. 
Notes were kept on all aspects of the excavation. The individuals excavating a structure recorded their impressions of the stratum on a standardized form, and a general narrative and impressions were recorded in a daily journal by the field supervisor. This journal was narrated to a person assigned the job of journal recorder in addition to other duties (Lois Flynn on this excavation). It has been found that the act of describing the impressions to another person defines and clarifies the observations, and the oral evaluation keeps the crew up-to-date on the current views of the field director. An informed crew digs more intelligently, and can supply ideas, interpretations, and insights which may not occur to the field director.

The photographic recording of the excavation was assigned to Augustine Frkuska who, in addition, maintained the log, and recorded the technical details of the photograph along with a brief description of the subject.

Transit measurements of depth or other explicit information were recorded by the crew member who made the measurement. Profiles were drawn by Augustine Frkuska after a detailed discussion of what was being observed, and were then checked by the field director.

Artifacts from specific strata and features were assigned a unique lot number. These lot assignments were done each night in the field, and a log was maintained recording the precise origins of the material in each lot. A second log was maintained indicating which lot numbers were assigned to specific units, strata, and/or features. All contained, in addition to the point of origin, such information as the name(s) of the excavator(s), the date of excavation, and necessary remarks. Lot numbers were cross-indexed onto unit/strata sheets.

When laboratory processing began, however, the artifacts received labels which gave their locations, rather than an abstract lot number. This was done to reduce the amount of back reference to lists of lot numbers and their locations. Such back-referencing greatly increases the chance of error and confusion.

All units were plotted on a field map which is reproduced here (Fig. 2).

\section{THE INVESTIGATIONS}

\section{Surface Surveys}

As part of this initial investigation of Las Cabras, an intensive surface inspection of the route to be followed by the access road to the future visitors' center and of the general location of the visitors' center itself was carried out. Several other areas indicated by local informants as having produced some artifacts or considered to be potential occupation areas associated with the Las Cabras structures were also intensively surveyed. The remainder of the future park area was walked over randomly, but not intensively.

Neither the access road nor the proposed visitors' center site showed any significant artifact concentrations. Twenty or 30 chert fragments were examined but were largely judged to be plow-broken cobbles. A very few are considered to be the project of a chert-knapping activity. These chert fragments were found almost exclusively along the northern quarter of the northeastern fence line of the Southern tract, and are probably from an aboriginal site across the fence line to the northeast (Fig. 1). 


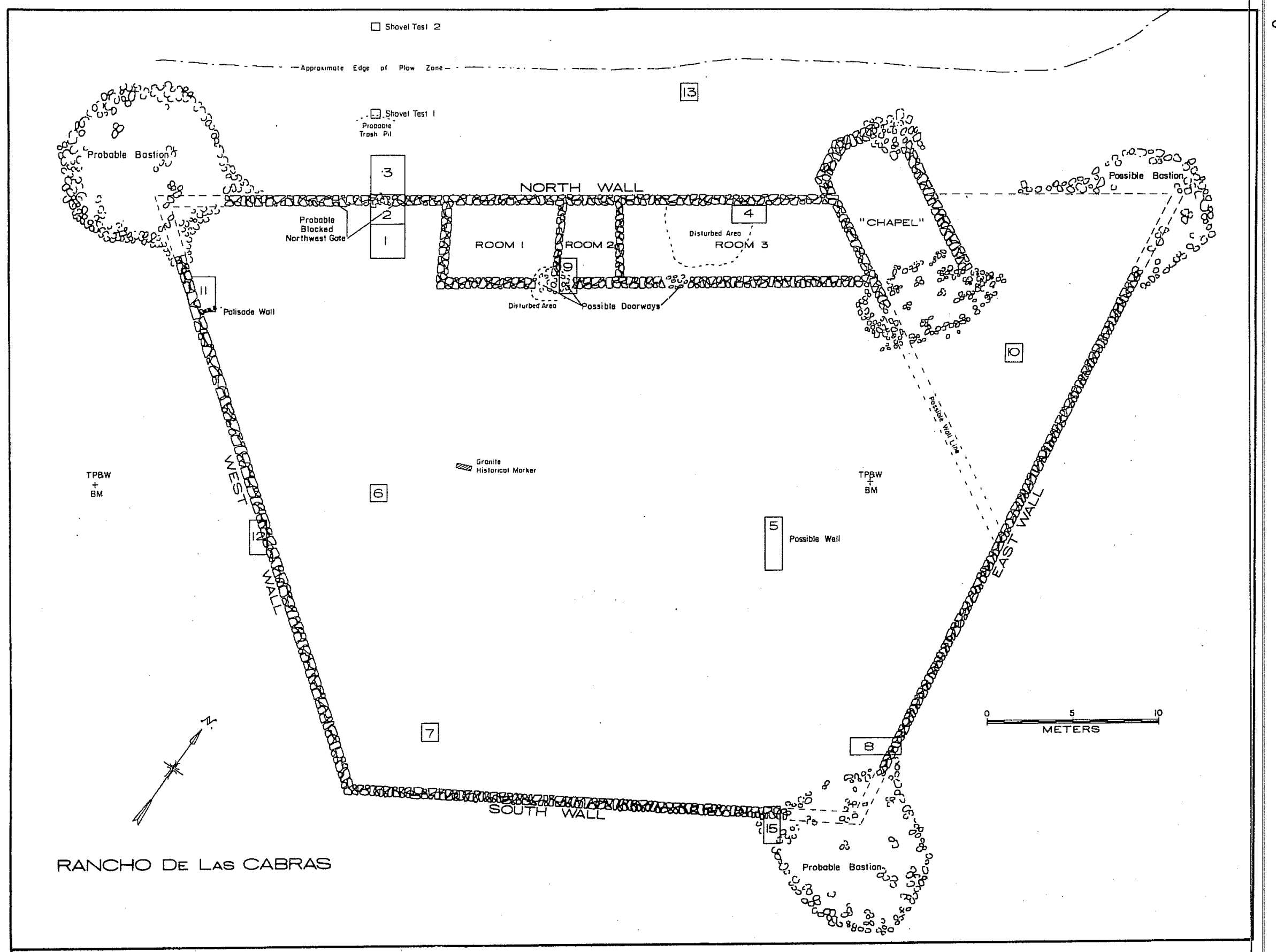

Figure 2. Map of the Site. 
Two Anglo stoneware sherds were picked up in a field just west of the future park property line, in an area where a local informant said he had seen some potsherds while plowing. No other artifacts were found, making it likely that these sherds were a random occurrence.

An intensive survey was done around the ruins of Las Cabras and over most of the south half of the Southern tract. No artifacts of any kind (other than a few beer cans and shotgun shells) were found, except in the areas immediately adjacent to the northwest and southeast angles of the compound wal1.

$\underline{\text { Surface Collection }}$

Artifacts found outside the southeast corner were of sufficient number to warrant collection, since it was thought that they would contribute some information about the history and culture of the site. These artifacts are listed in Table 1.

Shovel Tests

A series of $50-\mathrm{cm}^{2}$ shovel tests was carried out along north-south coordinate line 118 at five-meter intervals, beginning at five meters from the wall. They were intended to test the extent to which debris in the area of the northwest gateway was scattered away from the compound, and to locate the general edge of the plow zone surrounding the compound. Units which extended outside the wall on the south and west indicated that virtually no artifacts had been deposited in these areas.

Shove 1 test 1 showed a marked increase in artifact density with depth, and several strata high in ash and charcoal content were seen. The strata resembled those in Unit 3 (see below). At a depth of ca. $20 \mathrm{~cm}$, sterile yellow tan clay was encountered in the northern half of the test, but the artifacts and debris continued into the ground in the southern portion, and the bone and pottery fragments became much larger. The restrictions imposed by the site of the test stopped excavation at this point.

\section{Observations}

The feature encountered at the bottom of the test would appear to be an intentionally dug, vertical-walled pit filled with trash and garbage. The depth and limits of the pit are not known. The pit seemed to originate at a slightly higher level than the earliest occupation surface in this area.

Test Excavation Units

Each test unit excavated was placed in such a manner as to answer a specific set of questions, and each produced a distinctive set of data. We will discuss each unit separately in this section. The discussion will include the reasons for selecting the position of the unit, stratigraphy and features observed while the unit was being excavated, and the artifacts found in association with these components. Some interpretive discussion of selected features within each unit will be included. 
TABLE 1. PROVENIENCE OF ARTIFACTS FROM 1980 EXCAVATIONS.
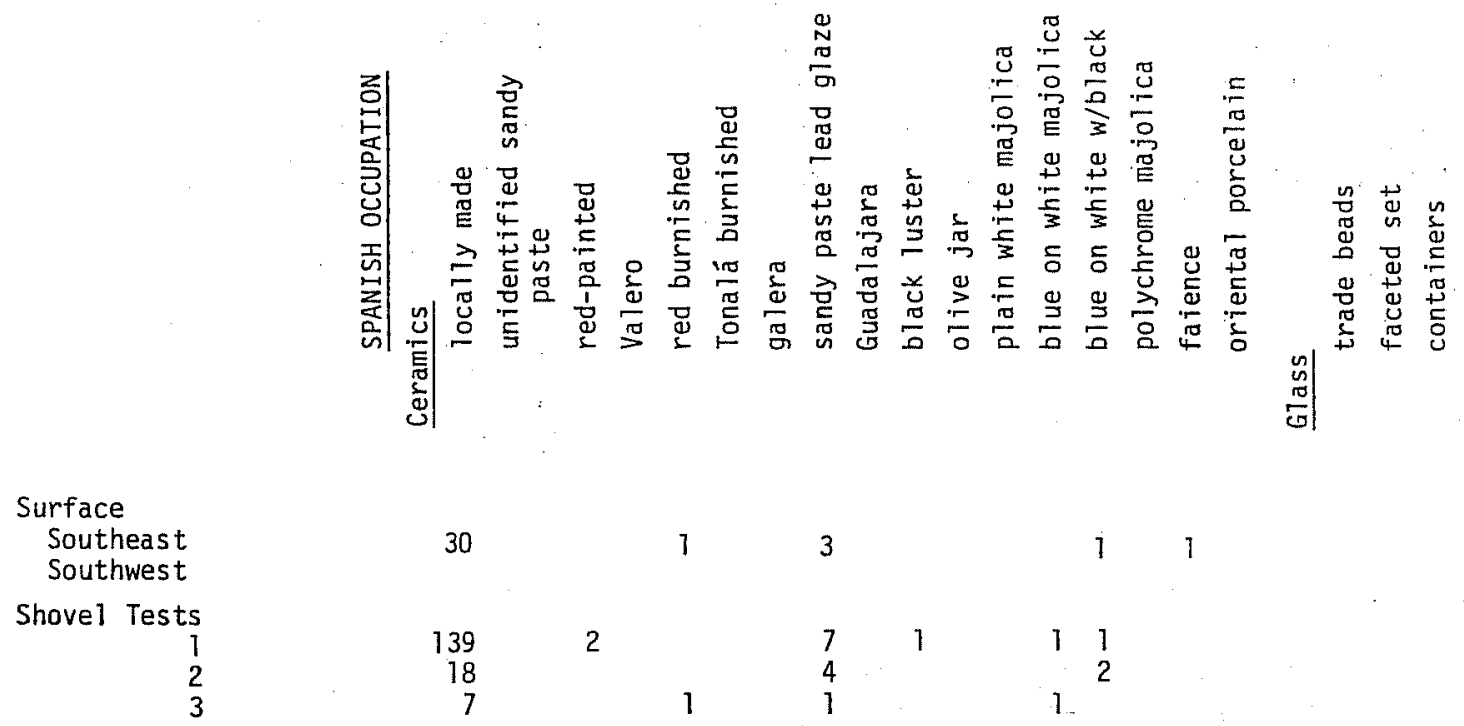

Unit I

Strat. 1

Unit 2

$\begin{array}{ll}\text { Strat. } & 1 \\ & 2 \\ & 3 \\ & 4\end{array}$

Features 1-4

2

1

Unit 3

strat.

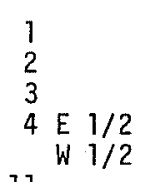

Feature 11

E $1 / 2$
W $1 / 2$

Unit 4

Strat. 1 E $1 / 2$

$\begin{array}{llll} & E & 1 / 2 \\ & W & 1 / 2 \\ 2 & E & 1 / 2 \\ 3 & E & 1 / 2 \\ 4 & E & 1 / 2 \\ 5 & E & 1 / 2 \\ 6 & E & 1 / 2 \\ 6 & & \end{array}$

15
5
6
8
5

$\begin{array}{lllll}9 & 1 & 1 & 3 & 1 \\ 2 & & 1 & & \\ 2 & & 2 & & \\ 3 & & & 2 & \end{array}$

1

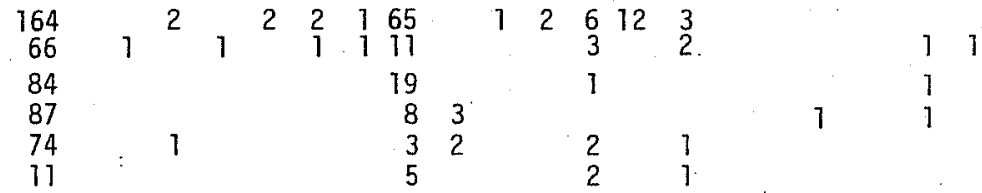

Feature

Unit 5

Strat. 1

Unit 6

$\begin{array}{ll}\text { Strat. } & 1 \\ & 2 \\ 3\end{array}$

1
2
3

Unit 7

Strat.

Feature 7

$\begin{array}{ll}1 & 3 \\ 3 & 7\end{array}$




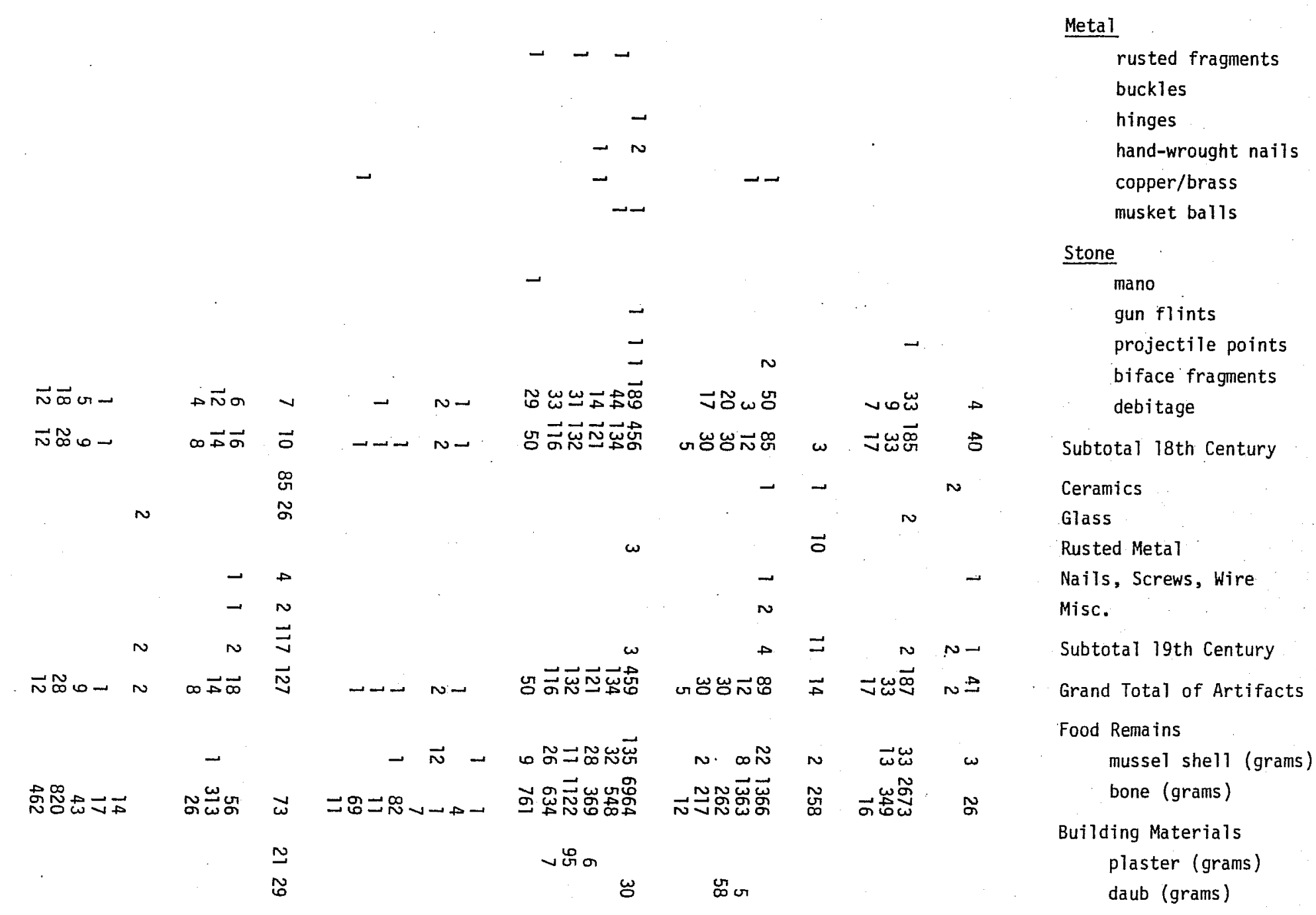


TABLE 1. continued

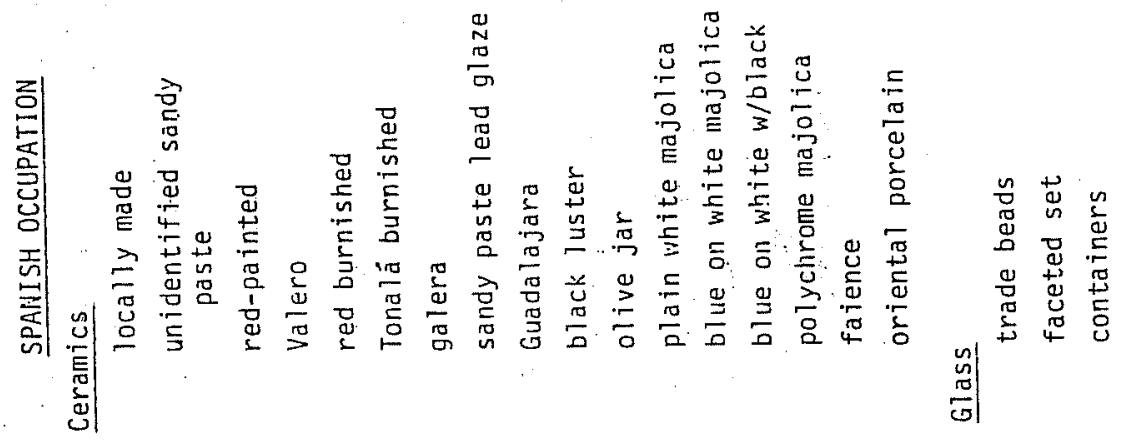

Unit 8

$\begin{array}{ll}\text { Strat. } & 1 \\ & 2 \\ & 3\end{array}$

2
5

$\begin{array}{ll}1 & 1 \\ 3 & 1\end{array}$

$\begin{array}{lll}11 & 1 \\ & 1\end{array}$

Unit 9

Strat.

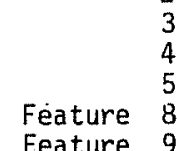

Feature

Unit 10

Strat.

1
2
3
4
5
6
7
8

Unit 11

Surface

Strat.

Feature 10

1

12

2

1

11

3
2

1

33

1

it 12

strat. $\quad ?$
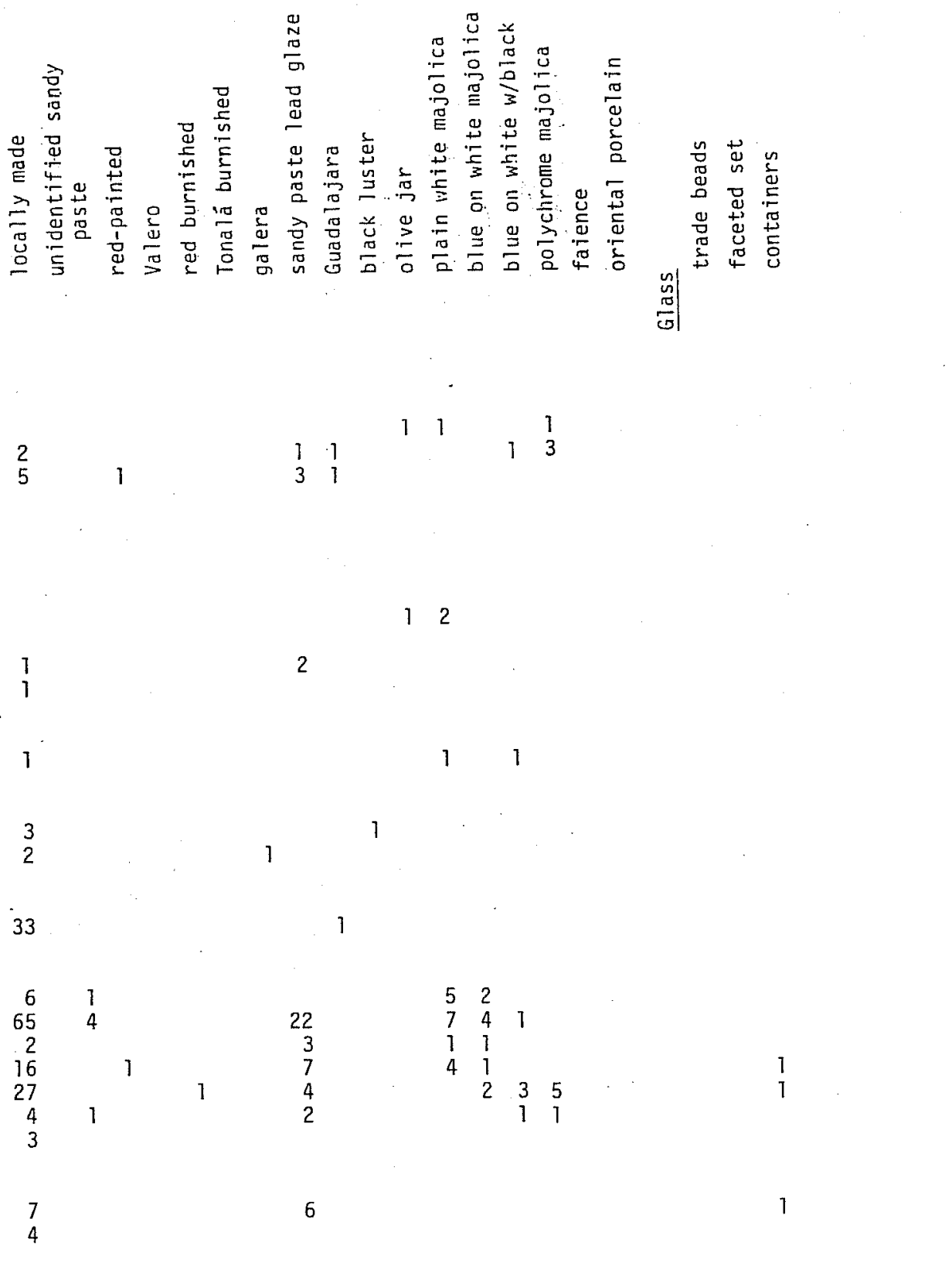

Unit 13

Strat.

1
2
3

Unit 14

$\begin{array}{rl}6 & 1 \\ 10 & 1\end{array}$

1
4
1

No Artifacts

Unit 15

strat.

$$
\begin{aligned}
& 1 \\
& 2 \\
& 3 \\
& 4
\end{aligned}
$$

Totals 
ฟี่

ज

जั

$\infty$

के

$\infty$

$\overrightarrow{0}$

ळ

N

s

w $N \omega$

๘ㅇํ웅

$$
v=
$$

NN

$$
\omega
$$

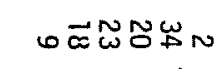

$$
\text { 范 }
$$$$
\text { กั }
$$

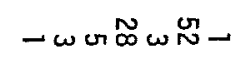

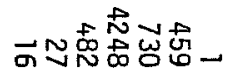

G $\rightarrow$

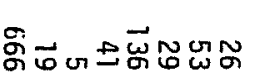

Evo
Metal

rusted fragments

buckles

hinges

hand-wrought nails

copper/brass

musket balls

\section{Stone}

mano

gun fiints

projectile points biface fragments debitage

Subtotal 18th Century

\section{Ceramics}

Glass

\section{Rusted Metal}

Nails, Screws, Wire

Misc.

Subtotal 19th Century

Grand Total of Artifacts

\section{Food Remains}

mussel shell (grams)

bone (grams)

Building Materials

plaster (grams) daub (grams) 
Units 1,2 , and 3 were established as a block on a portion of the north wall line where the wall structure was not visible above ground. They were intended as an initial look at the soil, stratigraphy, and the depth of original occupation below the present surface in this area. Other general information expected from these units was to determine if a wall was indeed present across the block of units and, if so, what problems, if any, might be encountered with its excavation.

Unit 1 was a $2-\mathrm{m}^{2}$ unit. Unit 2 was a $1 \times 2-\mathrm{m}$ unit against the south face of the wa11, and Unit 3 was a $2 \times 3-m$ unit against the north face of the wa11, and extending across it.

The surfaces of these units were cleared of brush and weeds, and the loose surface dirt was swept up and screened. It was decided that Unit 1 would be excavated onty if necessary to define features extending into it from Unit 2.

\section{UNIT 2 (see Fig. 3)}

\section{Stratigraphy}

Stratum 1 was dominated by fallen wall stones, in a matrix of tan, sandy soil. This stratum was $20-\mathrm{cm}$ thick at the south edge of the unit, and lensed out as it sloped upward to the top of the surviving wall stub.

Stratum 2 was a similar tan, sandy soil, but with a high percentage of ash stains and lenses, and a few large stones. It was 19-cm thick at the south edge of the unit, and its upper surface sloped up to the face of the extant wall. The lower surface bottomed onto a generally level, hard-packed gray surface of clay, ash, and charcoal. This surface had a slight slope downward toward the southeast corner of the unit. A large rodent disturbance about $30 \mathrm{~cm}$ in diameter penetrated this hard-packed surface in the northeast corner against the north wal1. The hard surface occupied most of the east half of the unit. The east half was badly disturbed by roots and rodent burrowing extending downward from the present surface. The area of rodent disturbance increased with depth.

Two post holes were recognized at the surface of stratum 2 near the center of the south wall of the unit. Upon the completion of the stratum, the post holes were seen to be associated with a disturbed area on the south profile, extending up into stratum 1 .

The hard-packed ash and clay were removed as stratum 3, and found to be multiple layers of ash, dirt, and burned clay ranging from 2 to $4 \mathrm{~cm}$ in thickness.

Stratum 3 rested on a hard yellow-tan clay surface, which was designated stratum 4. When the surface of stratum 4 was cleaned, an oval pit was found to have been dug into this surface. This pit was about $61 \mathrm{~cm}$ long and $35 \mathrm{~cm}$ wide, and extended some $20 \mathrm{~cm}$ below the surface of stratum 4. The entire interior of the pit was heavily fire-reddened, and this fire-reddening extended out onto the surface of stratum 4 about $5 \mathrm{~cm}$. The two post holes extending downwards from stratum 1 penetrated the south end of this fire pit. 


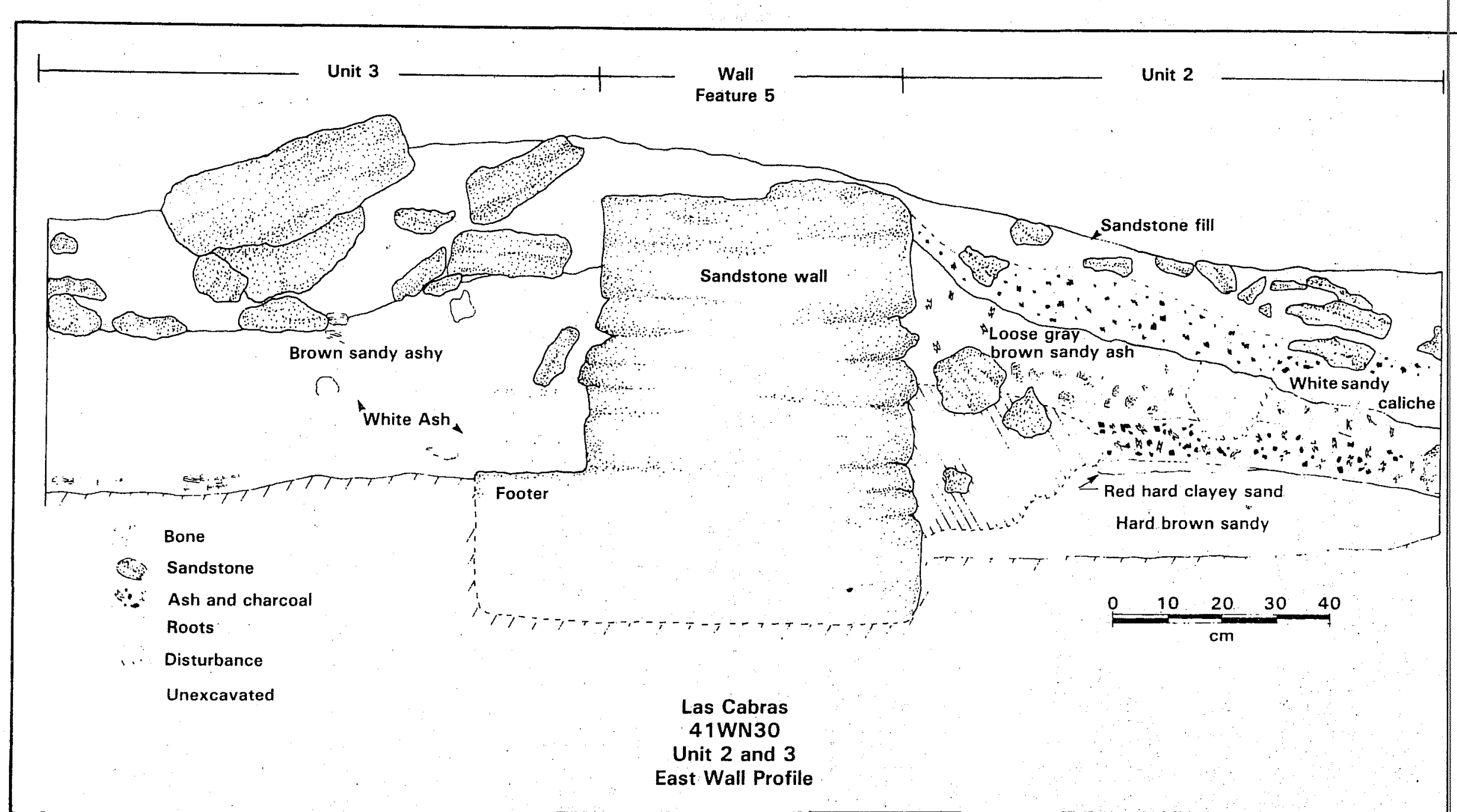

Figure 3. Profile of units 2 and 3. 
The pit was full of ash, charcoal, and sandy earth. The lowest $5 \mathrm{~cm}$ were packed with ash and large chunks of charcoal. The eastern half was a 4 to $5 \mathrm{~cm}$ thick lens of flat sandstone chunks and what appeared to be a sandy lime mortar. This lens had the appearance of spill rather than part of a sandstone floor. The western edge of the lens was broken by the rodent disturbance. The fire pit was apparently dug through the eastern edge of this lens of mortar.

Stratum 4 was excavated to a depth of about $18 \mathrm{~cm}$. It was found to be sterile except for the top $3 \mathrm{~cm}$ and a few artifacts found in rodent-disturbed areas. Very soon after beginning the excavation of stratum 4, traces of the footing trench for the north wall were located. Along most of the wall, the stones were flush with the inner face of the footing trench, but in some areas gaps of up to $4 \mathrm{~cm}$ were found. This footing trench was observed across only the eastern $70 \mathrm{~cm}$ of the wall face. The rest of the wall across the north side of this unit was irregular and had a larger footing trench, badly disturbed in Unit 2 by rodent activity.

\section{Observations}

The surface of stratum 4 appears to be the original occupation surface in this unit. Most artifacts in stratum 4 are apparentiy packed into its surface. During the time of this original occupation, a gate or doorway apparently existed in the wall at this point.

The area of spilled mortar and flat sandstone chunks in the west half of stratum 3 is probably from the filling of the gateway. After this opening was blocked, the fire pit was dug through the spilled mortar into the underlying occupation surface and the sterile clay beneath. Much of the ash. in stratum 3 is probably a product of this fire pit.

Stratum 2 is apparently a buildup of soil during a period of very low-level use, perhaps no more than an occasional overnight camp in the area. In fact, most of the artifact material in stratum 2 could be from root and rodent disturbance of lower strata. Stratum 1 is dominated by wall rubble. Most of the actual volume of the wall in this area is gone, probably through stone robbing, so stratum 1 contains mostly scrap stone and perhaps windblown dirt.

UNIT. 3 (see Fig. 3)

\section{Stratigraphy}

The stratigraphy of Unit 3 is quite similar to that of Unit 2. Stratum $1,23 \mathrm{~cm}$ thick against the wall and thinning out to $2-3 \mathrm{~cm}$ at $4 \mathrm{~m}$ from the face of the wall, is dominated by wall fall, with a hard tan, sandy clay fill. Portions of stratum 1 extend across the top of the wall, especially in the western half of the unit. A large quantity of bone was found in this stratum, more than in any other single stratum in these excavations.

Stratum 2 was a brown sandy clay with a large admixture of ash, somewhat more compacted than was stratum 2 inside the wall. The upper surface of this stratum sloped downward away from the wall, with a thickness at the wall of $22 \mathrm{~cm}$, and approximately $2 \mathrm{~cm}$ thick at $2.4 \mathrm{~m}$ from the wall. Stratum 2 overlaid a level surface with a patchy layer of ash and some charcoal, up to $1 \mathrm{~cm}$ thick in some areas. 
At this level, it was decided to reduce Unit 3 in size. The length along the wall was kept at $2 \mathrm{~m}$, but the width outward from the north face was reduced to $1 \mathrm{~m}$. The wall itself was designated as Feature 5. Stratum 3 was then begun.

Stratum 3 was almost level, $8 \mathrm{~cm}$ thick at the wall and $6 \mathrm{~cm}$ thick, $1 \mathrm{~m}$ from the north face of the wall. It was a gray sandy clay with some charcoal and ash, and had another thin layer of white ash and some charcoal at its base, similar to the one on its upper surface. No burned earth or fire-reddening was seen anywhere in the stratum.

Stratum 4 appeared to be a multiple-lensed, hard-packed scatter of bone, charcoal, ceramics, and other material. Since the appearance of the stone construction of the north wall differed so noticeably in the east and west halves of the unit, the unit was divided into an east and a west half to test for artifact differences.

As the last of stratum 3 was removed from the surface of stratum 4, a footing trench was found, dug from the surface of 4 . The irregular western portion of the north wall had been built in this trench. After most of stratum 4 had been removed, the surface of a footing was found along the eastern, well-built portion of the wa11, extending $20 \mathrm{~cm}$ out from its northern face. The footing was $70 \mathrm{~cm}$ long, and had a fairly distinct squared end. The footing trench for the western portion of the wall was irregular in shape and $20 \mathrm{~cm}$ wide at the western edge of the unit. Most of the stone was virtually dumped into the trench, and much of it was in relatively massive chunks, $30-40 \mathrm{~cm}$ across. Soft brown sandy. clay filled the spaces between these stones, and this earth was full of artifacts and bone. On the south side of the wall this trench faded into the rodent and root disturbance which occupied most of the west half of Unit 2 .

Stratum 4 became sterile at about the level of the surface of the footing. This is at about the same level as was the last occupation surface in Unit 2 (the top of stratum 4; see Fig. 3).

\section{Observations}

Stratum 4 is apparently debris from the first occupation in this area. This occupation began at the time the stone wall of the compound was built, and continued to collect to a depth of $6 \mathrm{~cm}$ against the base of the wall, and $13 \mathrm{~cm}$ at the north edge of Unit 3 (south section). During this period the wal1 ended $70 \mathrm{~cm}$ into the eastern edge of the unit, probably in a squared face, forming one edge of a gateway, either arched or open-topped.

At the end of this period the decision was made to seal this gateway, either completely or leaving only a small doorway somewhere west of Unit 3 . This sealing was done by digging a trench along the alignment of the wall in the gateway and building a roughly laid stone wall into this trench, filling the gateway. The persons building this plug had little or none of the expertise for stonework possessed by those who did the original construction.

After the gate was filled, the fire pit hearth was dug in Unit 2, and the heavy ash. buildup occurred. Which formed stratum 3 in that unit. This is reflected in the generally gray color of the deposits of stratum 3 outside the wall in Unit 3 . Then the site was effectively abandoned and stratum 2 built up from washout from the wall structure, blown in dirt, animal activity, and other random events. Stratum 1 is a product of the series of wall robbings and destruction beginning early this century. 
UNIT 4 (see Fig. 4 profile drawing)

Unit 4 was a $1 \mathrm{~m}$ by $1 \mathrm{~m}$ unit placed inside room 3 to examine the wall and any surviving floor surface, and to survey the extent of damage done to the room's living surfaces by a large treasure-hunter's pit about 15 feet wide along the wall and extending about 10 feet south from the wall face.

\section{Stratigraphy}

Stratum 1 is a layer of wall fall and natural soil buildup, sloping upward toward the wa11. Against the wall at the north side of the unit, this stratum was $54 \mathrm{~cm}$ thick; at the south edge of the unit it was $19 \mathrm{~cm}$ thick. This stratum sloped steeply downward toward the west into the large disturbed area, which penetrated the lower strata.

At the east end of the unit, stratum 1 bottomed onto a relatively level dark gray brown layer of earth. The lower half of stratum 1 was fairly free of stones, indicating that the wall deterioration was not occurring at any speed. In stratum 2, a noticeable increase in fist-sized or somewhat larger stone was seen. Stratum 2 was $10 \mathrm{~cm}$ thick, and overlaid a grayish brown, fine ashy sand with a few rocks. This sand was interrupted at a depth of about $10 \mathrm{~cm}$ by a lens of charcoal and ash, with some brown clay along the south side of the unit. This appeared to be the remains of a short-term event during the deposition of the sand, because beneath this lens, stratum 4 is virtually identical, being a gray-brown fine sand with some ash. The sand grain size seemed to be coarser in the lowest parts of the stratum.

Stratum 5 was a hard-packed, 1ight gray clay, with an irregular surface. It overlaid a loose tan clay, stratum 6 . At the bottom of stratum 6 was found a hard, light gray-tan sandy lime surface, apparently a floor. On this floor was a fragment of copper sheet, $11 \times 12 \mathrm{~cm}$, with irregular edges and one rivet stil1 in place near one edge. The hard sandy lime surface was only along the south side of the unit, ending in an irregular line with a $2 \mathrm{~cm}$ drop-off to a hard-packed earthen surface. The treasure-hunter's pit continued through this floor and on into hard, yellow-tan sterile clay. This disturbed area was removed to a depth of ca. $5 \mathrm{~cm}$, sufficient to show that the hard sandy-lime floor was about $3 \mathrm{~cm}$ thick.

\section{observations}

As Table 1 shows, there were very few artifacts found in this unit. Those that were found, other than the copper sheet lying on the sandy lime floor, are apparently randomly scattered objects, not representative of an occupational deposit.

It would appear from the stratigraphy that there was no major destruction event at the end of the primary occupation-no burned roof debris or collapsed wall on the floor, for example. The simplest explanation of the stratigraphy is that the building was abandoned and the roof rotted away with no effects of fire and no subsequent occupation, except a brief interval represented by the thin lens of ash and charcoal at the top of stratum 4. If the roof was of clay and caliche supported by large log roof-beams, then this roof structure decayed and dissolved slowly over a long period of time, slowly depositing the roof material into the room. The approximately level deposits of sand, clay, and caliche are about 40 


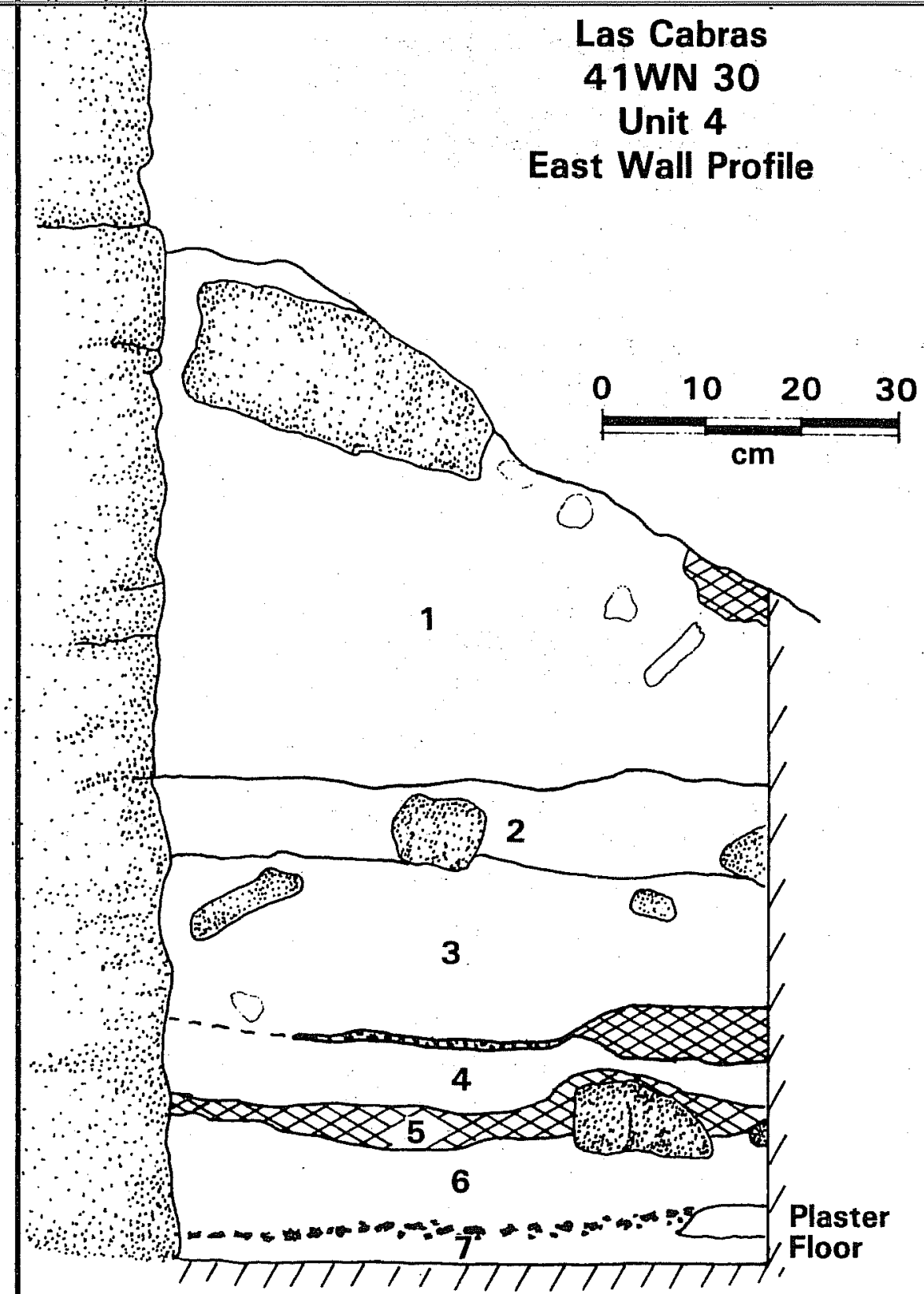

1. Light brown sandy clay loam

2. Dark grayish brown

3. Loose grayish brown ashy sand

4. Loose grayish brown, large grained

5. Light gray packed adobe-like material

6. Soft fine-grained tan silty clay

7. Hard packed dirt floor 
$\mathrm{cm}$ thick, which is on the order of thickness to be expected from the decay of an adobe roof (Santleben 1862:23). It is considered a reasonable assumption, based on these observations, that room 3 had a flat adobe and caliche roof, supported by beams (vigas), and that through long-term decay the majority of the roof is now the fill of the room.

UNIT 5

Unit 5 was placed in the west center of the compound in order to examine a depression which local informants indicated might be the well. A $1 \times 3 \mathrm{~m}$ unit was established, divided into three $1 \mathrm{~m}^{2}$ sections labeled $5 \mathrm{~A}, 5 \mathrm{~B}$, and $5 \mathrm{C}$. The long axis of the rectangular unit extended grid north.

\section{Stratigraphy}

Although an attempt was made to excavate this unit by natural strata, the attempt was unsuccessful, since no apparent stratification appeared. The soil was a hard, gray clay which changed gradually to a softer, gray clay. This ended on a hard flat surface of gray clay which seemed to resemble the hard-packed surface of the patio encountered elsewhere. The excavation stopped on this surface.

The depression capped a circular area of darker clay with circular cracks within and around it. Anglo artifacts were found to the base of the excavation, but only in this area. When the digging was halted, a large piece of barbed wire was visible in the circular stain.

\section{Observations}

It is apparent that some feature exists in the ground at this point. Exactly what sort of feature will have to await a more detajled excavation. The lack of any masonry construction could indicate that this is merely an Anglo trash pit, but the masonry could be lacking because the unit did not go deep enough to reveal any such structure.

UNiT, 6

Unit 6 was placed a short distance inside the supposed gate through the west wall. It was intended to examine the amount of deposition near the interior of the gateway, in order to compare with the expected deposition outside the gateway. (Unit 12, discussed below, later showed that there was no gate through the west wa11). A second purpose was to examine the stratification in the central area of the compound in order to compare it with other parts of the compound.

\section{Stratigraphy}

Stratum 1 was 4 to $6 \mathrm{~cm}$ thick and was a hard-packed gray clay with some artifacts. This graded into stratum 2, a less hard-packed stratum with fewer artifacts. It ended on a hard, flat earth surface of gray clay. Only the top centimeter of this stratum contained artifacts. 
Observations

Very little deposition occurred in this area of the site. It is probable that much of the central area of the compound will have a similar depositional history.

UNIT 7

Unit 7 was established in the southwestern angle of the compound to sample the stratigraphy in this area and to check for traces of structures which might have been built in the angle.

\section{Stratigraphy}

Stratum 1 was a loose, tan dirt containing a few fragments of a modern beer bottle. The stratum was $1 \mathrm{~cm}$ thick.

Stratum 2 was a more firmly packed tan clay, relatively flat and $5 \mathrm{~cm}$ thick. It contained only a few fragments of bone.

In stratum 3, several components were found. These consisted of two layers of animal manure with a layer of tan silty clay between. The upper component of manure, $10 \mathrm{~cm}$ thick, was fragmented into small pieces, while the lower was in large chunks, and was $13 \mathrm{~cm}$ thick.

Stratum 4 was a dark gray-brown, ashy-looking sand $6 \mathrm{~cm}$ thick, and contained two ceramic sherds and some bone fragments. It appeared to be dust or dirt which had collected onto the underlying hard-packed gray clay surface, stratum 5 .

Stratum 5 contained several sherds in its top 2 to $3 \mathrm{~cm}$. Below this occupation surface the hard clay was sterile.

In the southwestern quadrant of the surface of stratum 5 was a post hole ca. $15 \mathrm{~cm}$ in diameter. This post hole had rocks packed into it around its edges, apparently to wedge the post into place. The post hole extended $45 \mathrm{~cm}$ below the surface of stratum 5 .

\section{Observations}

The hard-packed earthen surface of stratum 5 resembled that found in Unit 6, but the overlying dark ashy sand is not seen in that unit. No explanation for this odd stratum can be offered.

After the unknown episode which produced this dark, sandy layer (stratum 4), the same manure deposition occurred here as occurred in Units 8 and 10 below. The thickness of the manure layer and its restriction to the southern and eastern portions of the compound may indicate that the animals producing the deposition were penned here, separated from the rest of the compound by a fence. 
UNIT 8 (see Fig. 5)

Unit 8 was established to test for possible structures within the southeastern angle of the compound, and to examine the strata in this area. It was a $1 \times 2$ $m$ unit with its long axis east and west.

\section{Stratigraphy}

Stratum 1 was a hard-packed, light brown clay and sand layer with a considerable amount of stone debris. It ranged in thickness from $10 \mathrm{~cm}$ near the wall to $4 \mathrm{~cm}$ at the west end of the unit.

Stratum 2 was a thick layer of manure ca. $31 \mathrm{~cm}$ deep. It was divided into two horizontal components as were the manure strata in Units 7 and 10. The upper component was $12 \mathrm{~cm}$ thick and consisted of fragmented manure in a matrix of brown sandy silt, while the lower was $18 \mathrm{~cm}$ thick and was much more solidly bedded, with fine multiple strata visible in the fragments as they were removed. A $1 \mathrm{~cm}$ thick lens of sandy silt with no manure separated the two components at the east end of the unit against the wall. This lens thickened to $8 \mathrm{~cm}$ at the west end of the unit, and the overlying manure component thinned to $8 \mathrm{~cm}$ at the same point. Most of the artifacts from stratum 2 came from this lens of manure-free sand.

Stratum 3 was fairly dark, dusty tan sand 2 to $4 \mathrm{~cm}$ thick, with patches of brown clay. It was packed onto a hard, tan sandy plaster floor. The sand and dirt stratum contained most of the artifacts, but several potsherds were embedded in the surface of the floor plaster.

The decision was made to leave the plaster floor undamaged at this stage of the excavations.

\section{Observations}

It is assumed that the plaster floor was inside a structure in this southeastern corner. If so, the structure left no hint on the present ground surface of walls separating the floor from the rest of the compound, so far as could be seen while examining the present surface in the area. In addition, the lack of a thick deposit of clay and adobe on the floor indicates that there were no substantial walls supporting a flat caliche roof over the floor, as room 3 appears to have had. This probably indicates that the structure had wooden walls and a thatched roof.

The manure layers resemble those found in Units 7 and 10, both in general thickness and the structure of the two components. They undoubtedly all represent the same two phases of a usage of the compound as a cattle or sheep pen. Because of the great similarity in deposition between the various areas where the manure was seen, it is likely that the building surrounding the floor found in Unit 8 had fallen, and did not separate it from the other areas containing animals.

\section{UNIT 9}

Unit 4 supplied only a very limited look at the stone structures along the north wall. Peculiarities in the wall lines of the south side of these structures 


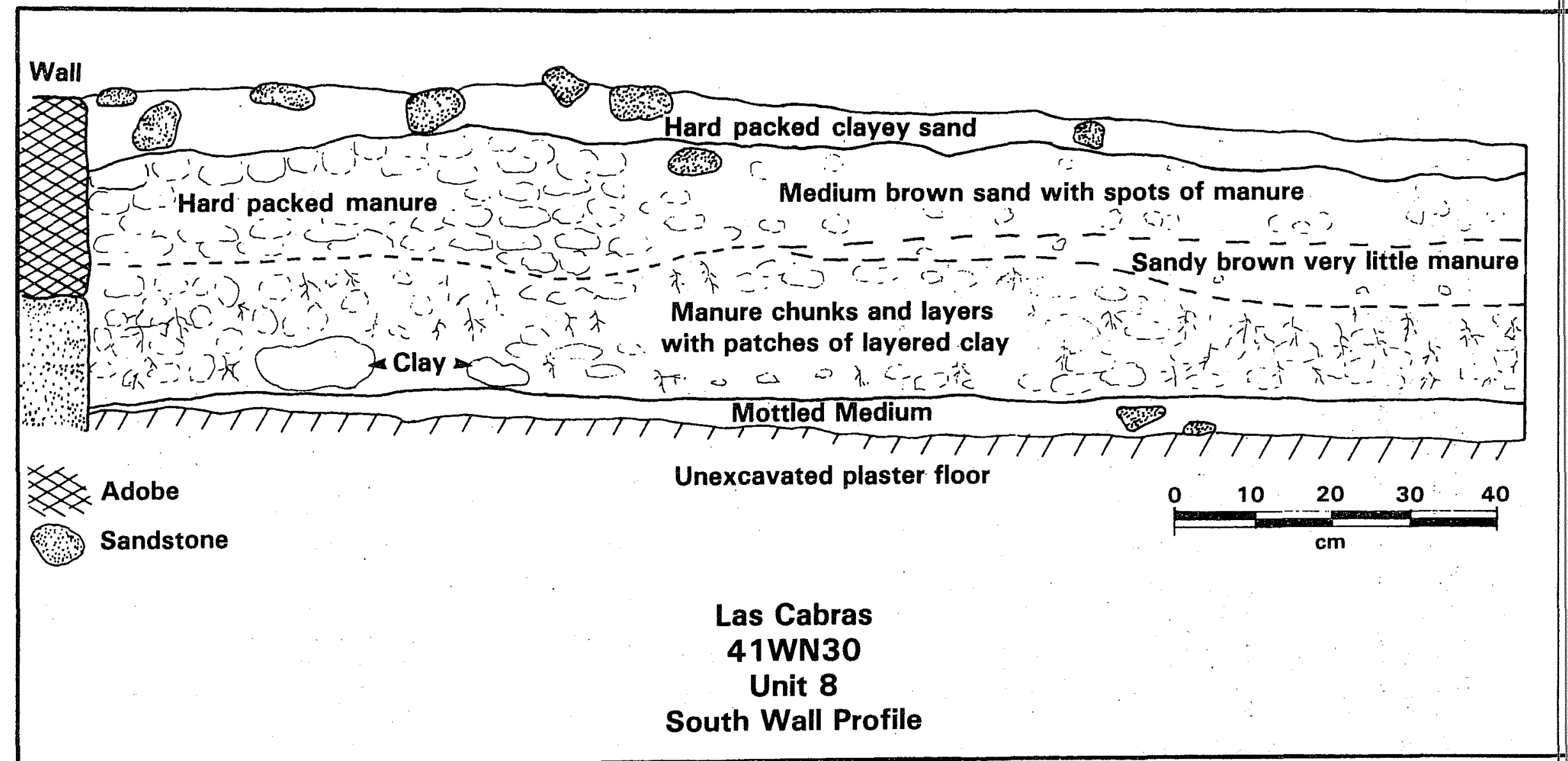

Figure 5. Profile of unit 8. 
indicated the possibility that a doorway existed at the southwest corner of room 2, in conjunction with a treasure-hunter's pit. Unit 9 was established to examine the interior of a portion of room 2, and at the same time check for the presence of a doorway in the southwestern corner of the room.

\section{Stratigraphy}

Although a stratigraphic excavation of the unit was carried out, examination of the stratigraphy in the walls of the unit after its completion indicated that the room fill had been seriously disturbed, both by previous excavation and by rodent holes. A floor level was reached at a depth of below the top of the wall. This floor surface was extremely broken up and disturbed, but retained enough of its characteristics to make us fairly sure of its identification.

This floor appears to have been of a dark, hard-packed, orange-tan sandy clay, which may or may not have had a plastered surface. The area of the possible doorway was excavated to within a few centimeters of the level of this surface, but when the very disturbed condition of the original surface was recognized, the excavation was halted. If a doorway is in this area, then the excavation of it should be done in a much more exacting manner than could be managed in a $1 \mathrm{~m}^{2}$ unit.

\section{Observations}

The multiple, disturbed strata found in room 2 indicate that much of the present fill of room 2 is probably treasure-hunter's back dirt, and it would appear that most of the southwestern corner has also been disturbed by the same process.

It is very likely that the doorway into this room was in this corner. The only other possible place for it is the center of the room's west wa11, connected with room 1. Careful excavation could possibly record the remains or imprint of woodwork in this doorway, if it survived the disturbing effects of the treasure-hunter's pit.

UNIT 10 (see Fig. 6)

Unit 10 was a $1 \times 1 \mathrm{~m}^{2}$ unit placed on the alignment of the east wall of the chape1. One of the reasons for the location of this unit was to check for any extension of the wall of the chapel across this area. A second purpose was to examine the stratigraphy at the probable front of the chapel.

\section{Stratigraphy}

Stratum 1 ranged from 14 to $20 \mathrm{~cm}$ in thickness, and was hard-packed clay with some sandstone debris, without any patterning. This stratum ended with a $2-3 \mathrm{~cm}$ thick zone of red-brown sandy clay and ash in thin level lenses, forming the division between stratum 1 and stratum 2 . 


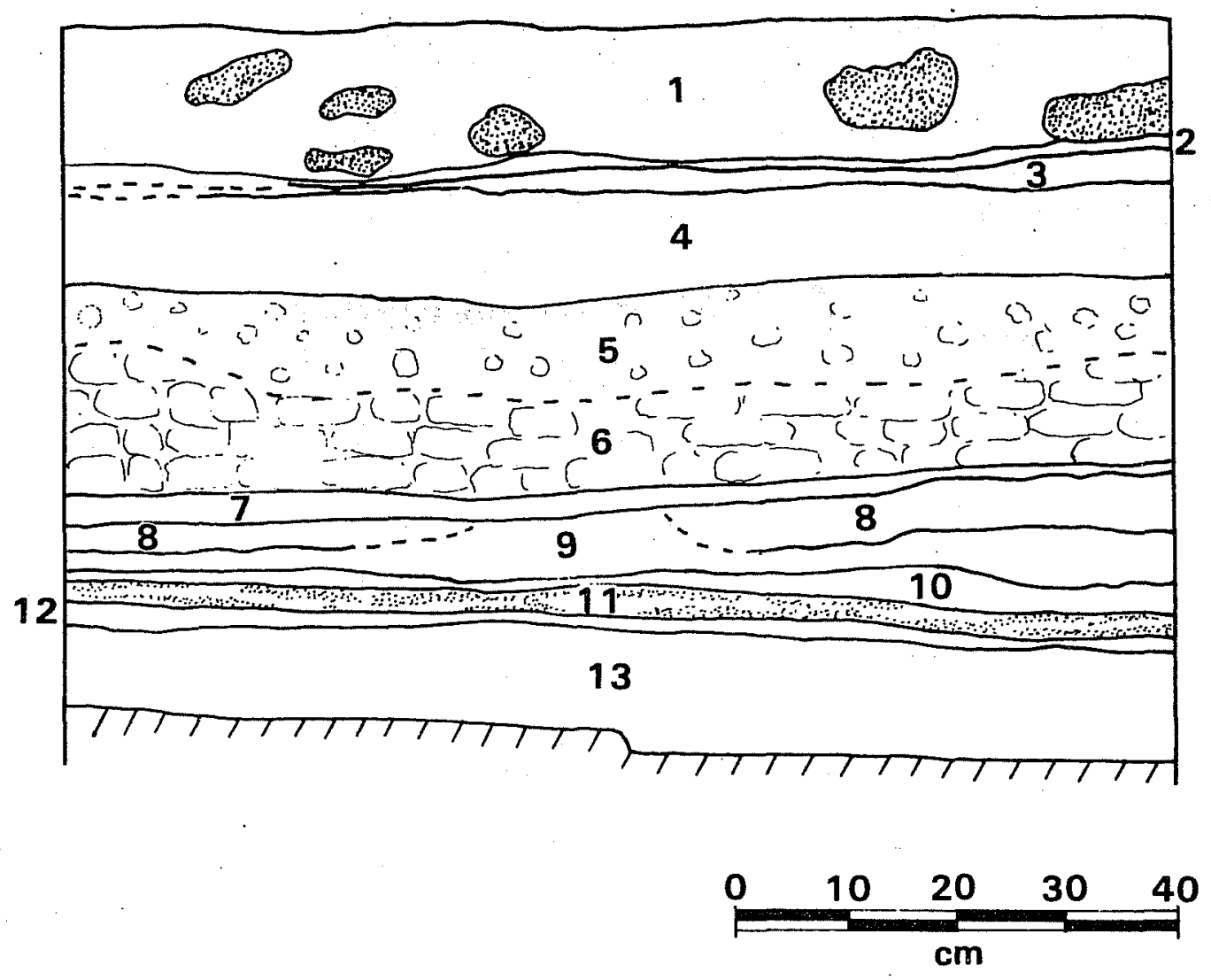

1. Light gray clayey loam with spots of caliche

2. Reddish brown sand

(2) Sandstone

3. Light gray sandy ash

4. Loose medium gray brown sandy loam

5. Fine pieces of manure with sand

6. Manure in layered chunks

7. Reddish tan soil

8. Dark brown charcoal stain

9. Medium brown fine sandy loam

10. Hard packed brown sand with ash

11. Layered white plaster

12. Reddish brown hard packed sand with clayey loam

13. Hard, light tan sandy clay

\author{
Las Cabras \\ 41WN30 \\ Unit 10 \\ East Wall Profile
}

Figure 6. Profile of unit 10. 
Stratum 2 was a medium gray-brown sandy loam, relatively soft, ranging from 17 to $20 \mathrm{~cm}$ in thickness. It overlaid a thick layer of animal dung, forming stratum 3. This layer was divided into two horizontal components, as was found in Unit 8 . Each was about 8 to $10 \mathrm{~cm}$ thick. As in Unit 8 , the upper component was broken into small chunks mixed with fine tan sand, while the lower component was in large pieces of dung with a clear multiple-layered structure and some fine tan sand.

Stratum 4 was a thin zone of fine red-tan sand ranging from 0 to $4 \mathrm{~cm}$ in thickness, thicker toward the west. Beneath this was a complex multi-lensed stratum, stratum 5, which was made up of lenses of dark brown clays, ash, charcoal, stains, and light to medium brown sandy loam. The bottommost component of this stratum was a thin layer of tan sand with ash, which was ca. $1 \mathrm{~cm}$ thick along the east side of the unit, and lensing out toward the west.

This was deposited onto a hard-packed surface which was a mixture of white 1 ime and tan clay forming stratum 6 . The stratum was about $5 \mathrm{~cm}$ thick, and fairly flat and level. At its base it graded into a very sandy stratum (7), with chunks of lime and some charcoal. On the eastern side of the unit there was some indication of fire-reddening of the tan clay surface beneath this stratum.

Stratum 8 was a tan, sandy clay, with artifacts only in the top 2-4 cm. Along the eastern edge of the top surface of this stratum were darker brown areas and some apparent fire-reddening. Excavation was stopped when the clay became sterile at about $64 \mathrm{~cm}$ below the surface.

\section{Observations}

The original occupation surface in this unit appears to have been the top of stratum 8. The pattern of hard-packed tan clay with impressed artifacts is seen also in Units 2, 3, and 11. In Unit 11, this surface had two hearth features similar to that seen as just beginning along the east edge of Unit 10 . The artifact collection for the surface of Unit 10 was sparse, but typical of the collections from the primary occupation elsewhere.

Strata 6 and 7 are anomalous and unique to this unit. The lime fragments found in these two strata were not a plaster floor, but rather broken fragments of white plaster, white lime, sandy mortar, small limestone chips with white lime or mortar adhering to them (some are fire blackened under the lime coating), and tan, sandy clay, which could be broken-down clay mortar. This stratum would appear to be broken debris, possibly from a plastered and white-washed finishing layer on the wall of a structure, or from a plaster floor. After this deposition of plaster chunks, there was a midden-like deposition again resembling that in Unit 11, but far less productive in bone and artifacts, and much thinner. This occupies the position of the dark gray brown ashy sand in Unit 7 . Above this was deposited the massive slabs of multiple-layered animal dung with intermixed sandy clay, the same sequence seen in Units 7 and 8 , but not in 11 or 6 .

\section{UNIT 11 (see Fig. 7)}

The presence of a gateway on the northwestern portion of the compound wall led us to surmise that there might have been a gatehouse structure in the northwestern 


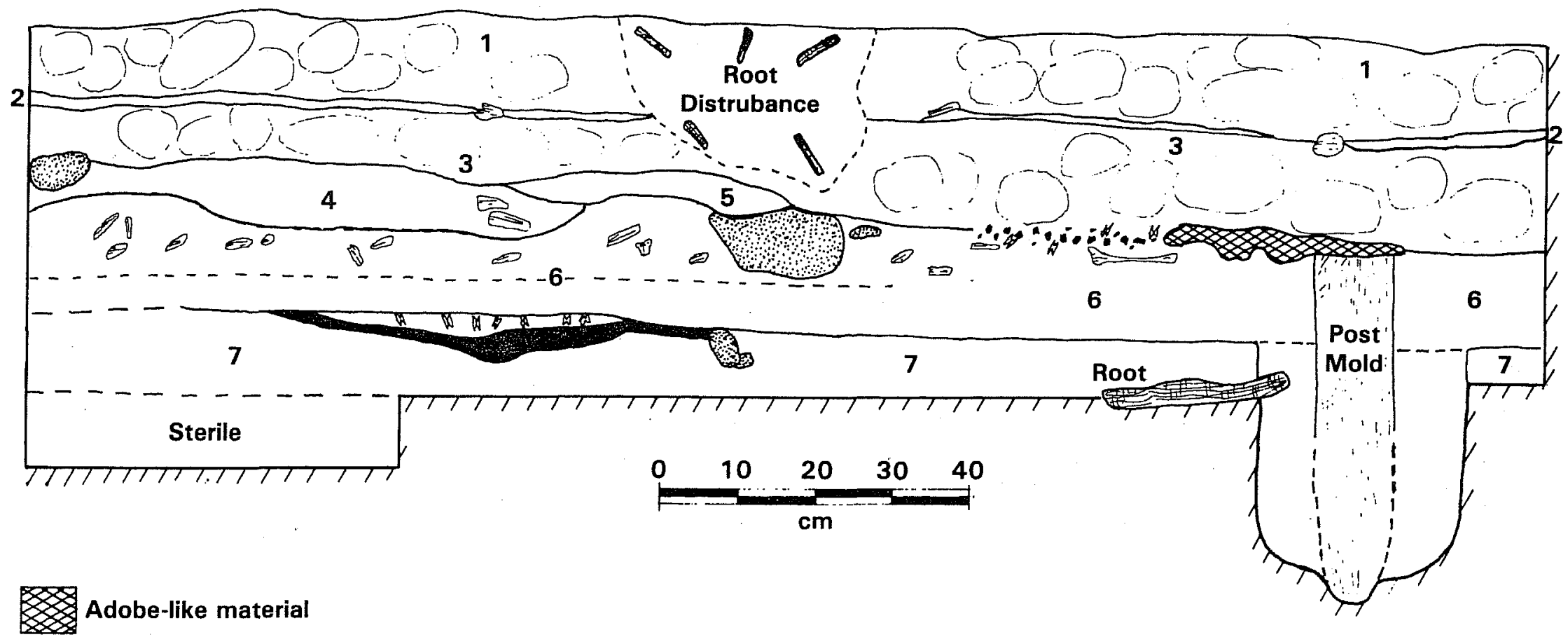

A Ash

O Bone

Charcoal

1. Sandy loam high in clay

2. Light gray sandy ash with bone

3. Loose sandy loam

4. Light yellow brown clay and sand mix

5. Clay and sand mix

6. Reddish brown loose sandy loam

7. Hard packed sandy loam

Las Cabras

41WN30

Unit 11

/// Unexcavated

Figure 7. Profile of unit 11. 
corner. Unit 11 was placed so as to examine the stratigraphy in the area of this corner and to test for a wall at the same distance south from the north wall as are the standing stone walls of rooms 1,2 , and 3 . The unit was $1 \times 2 \mathrm{~m}$ in size, with its long axis to grid north; the west side of the unit was extended beyond the one meter point up to the wall line, which ran toward the northwest in this area.

\section{Stratigraphy}

Stratum 1 was characterized by a large quantity of small stones, probably associated with wall fall. A surprising amount of ceramics and other cultural material was found on the surface and in stratum 1, more than was usual in other units. The stratum was a gray-brown sandy clay of a constant 10-12 cm in thickness, and rested on a 1-2 cm thick zone of light gray sand, ash, and scattered bone fragments, the top components of stratum 2 .

Stratum 2 was ash-stained in its upper several centimeters across most of the unit, but was basically a brown, sandy clay. A number of rocks were found together in the south quarter of the stratum, and scattered bone and ceramics in the remainder. The deposit showed few of the characteristics of a buildup on an occupation surface. This stratum ranged in thickness from $8 \mathrm{~cm}$ in the northern end of the unit to $14 \mathrm{~cm}$ in the south.

Stratum 3 began as a series of lenses of ash, charcoal, and some clay and caliche scattered across the unit. These ranged in thickness from 2 to $12 \mathrm{~cm}$, and a large quantity of articulated bone was intermixed. Large areas of red-brown clay were intermixed. Toward the base of this stratum, the areas of ash, charcoal, and caliche disappeared, and the bone concentration rapidly dropped off. The last several centimeters of the stratum were a red-brown sandy clay virtually free of bone. The total thickness of the stratum, including the ash lenses and other debris, ranged from $18 \mathrm{~cm}$ in the north to $13 \mathrm{~cm}$ in the south, with a maximum thickness of about $20 \mathrm{~cm}$ in the central area of the unit.

Stratum 3 bottomed onto a hard-packed, flat surface. A number of artifacts were packed into this flat surface, and two fire hearth features were located in the north end of the unit. One, near the center of the north wall, was a series of thin layers of ash and. charcoal overlying a circular bed of small gravel placed in a shallow bowl-like depression, with considerable fire-reddening of the clay in and around the depression. The second hearth was bisected by the east wa 11 of the unit, and was similar in plan and structure, being multiple ash and charcoal layers in a shallow bowl-shaped depression. This hearth had no gravel bedding in the depression. Both features were about $35 \mathrm{~cm}$ in diameter.

A mass of rocks in the base of stratum 2 along the south side of the unit was found to be resting on an area of discoloration and associated rodent holes in stratum 3 . As stratum 3 was removed in this area, this discoloration began to look more and more regular, and by the time the surface of stratum 4 was reached, the area had resolved itself in the clear outline of a footing trench surrounding a line of circular postmold stains. The trench outlines extended eastward at right angles to the west wall. It had parallel sides and a rounded west end, stopping just short of the stone wa11. Subsequent excavation of this trench as feature 10 showed that the trench was about $30 \mathrm{~cm}$ wide and $31 \mathrm{~cm}$ deep below the surface of stratum 4 , with straight vertical sides. The clear trace of the mold of one of the posts could be seen extending from the bottom of the trench through stratum 3 
to its top surface. A row of small, shallow depressions was found on the bottom of the trench, apparently the impression of the ends of the posts. The trench fill was a tan, sandy clay, with a paler yellow clay intermixed at the actual surface of stratum 4 .

The artifacts in stratum 4 were found predominantly in the top 2 to $4 \mathrm{~cm}$. At a depth of $8 \mathrm{~cm}$, the red-brown clay changed to a darker, harder clay. $A 50 \mathrm{~cm}^{2}$ sampling pit was dug into this stratum an additional $10 \mathrm{~cm}$; it was found to be sterile after the first centimeter. Artifacts in the lower portion of stratum 4 and on the surface of stratum 5 were localized into three small areas, each about 15 to $20 \mathrm{~cm}$ across. The general characteristics of these areas suggest that they were rodent disturbances.

\section{Observations}

The original occupation in this unit appears to have been on the surface of stratum 4. A considerable number of artifacts were pressed into this surface.

After a period of time the jacal wall trench was cut into this deposit. It cannot be determined whether the structure associated with this wall extended to the north or the south of it. The nature of the material deposited against the jacal wa11 in stratum 3 seems to indicate that it is the buildup from garbage dumping and fire hearth cleaning--a kitchen midden. At present it is assumed that this type of deposit is characteristic of a buildup outside a structure, near a doorway.

The top of stratum 3 apparently represents the destruction of the jacal and the cessation of occupation in this area, except for a possible short-term visitation represented by the thin ash and charcoal layer dividing stratum 1 from stratum 2. Strata 1 and 2 are predominantly recent soil and wall collapse debris.

\section{UNIT 12}

There was a gap in the line of rubble marking the west wall position, which was considered to be a gateway some $2 \mathrm{~m}$ wide. Unit 12, a $1 \times 2 \mathrm{~m}$ unit with its 1 ong axis towards the north, was situated at the south edge of this opening. It was intended to examine the stonework at the edge of this gateway (if it were one) and to examine the cultural deposits in the gateway opening and against the outside of the west wall.

\section{Stratigraphy}

Stratum 1 in the south end of the unit was the usual stone robbed wall rubble found in most of the units situated against the wall. Random fragments of sandstone up to 10 to $12 \mathrm{~cm}$ across in a matrix of tan, sandy clay were piled against the surviving wall fragments; this overlaid a flat surface of tan, sandy clay; the ground surface at the time the wall collapsed or robbing began. This surface is ca. $5 \mathrm{~cm}$ below present ground surface at the face of the wall.

In the northern portion of the unit, no wall fall or equivalent stratum was seen. 
Stratum 2 was a hard, tan, sandy clay with charcoal chunks of caliche mortar apparently from the bonding material in the wall, and some artifacts.

Artifacts became more scarce as the stratum was excavated. At $25 \mathrm{~cm}$ below the present surface this stratum bottomed onto a flat surface of brown loam.

This brown loam formed stratum 3. As it was excavated, no artifacts were found. The stratum was $10 \mathrm{~cm}$ thick, and overlaid a stratum of caliche, pebbles, and brown clay, which became more solidly caliche within the first 2 to $3 \mathrm{~cm}$. This was stratum 4, and was also sterile.

The footing trench for the wall was found to have been excavated from the top of stratum 3, and was $25 \mathrm{~cm}$ deep below that surface, extending $15 \mathrm{~cm}$ into the stratum of caliche. The footing was well built and consisted of rough stone laid into a bedding of hard, light gray mortar which filled the trench. There were some charcoal fragments intermixed with the mortar.

The wall extended across the entire length of Unit 12 with no sign of any break.

\section{Observations}

The apparent gap in the structure of the west wal1 on the surface may be the result of extensive stone robbing or even bulldozing, but does not reflect the actual structure of the wa11. The lack of any artifact deposition of note outside the wall is taken to indicate that no doorway or gateway was near this portion of the wal1, and indicates that very little occupation occurred outside of the wall.

UNIT 13

A local informant indicated that a circular structure resembling a 1 ime $\mathrm{kiln}$ had been found outside the north compound wall while the area around the site was being plowed. In an attempt to locate this structure, Unit 13 was placed outside the north wall near room 3 in a bowl-shaped depression of about $4 \mathrm{~m}$ in diameter.

\section{Stratigraphy}

Stratum 1 was an almost sterile hard tan clay, $10 \mathrm{~cm}$ in thickness. It overlaid a multiple-lensed stratum of silts and ash with charcoal, burned bone, and some ceramics, all excavated as stratum 2.

Beneath the zone of burned material and artifacts was a zone of almost sterile dark brown clay containing only a few bones. This zone was included with stratum 2. The total thickness of stratum 2 was $34 \mathrm{~cm}$.

Stratum 3 was a lighter, sandy-brown clay with numerous bones and some ceramics. Some ash and charcoal were present. Several large bones were found in the southwestern corner of this stratum, including an almost complete bovine skull showing distinct butchering marks. 
Stratum 3 ended on a yellow-white caliche surface which sloped steeply up from the southwest corner of the unit toward the northeast. The unit was too small to determine whether this surface was part of a man-made hole or a natural feature of the ground in this area.

\section{Observations}

It is possible that the feature found in the bottom of Unit 13 was a trash pit dug by hand or a dump into a natural depression or gully. The artifacts are not very concentrated, however, and a firm identification of the deposit must wait for further work in the area.

The bovine skull found in stratum 3 had been opened with an ax or butcher knife. The back of the skull is gone, implying that the brain was being removed. The flesh on the skull was not cooked off, since the skull was apparently still fully fleshed when it was dropped into the dump; several large fragments of the base of the skull were found broken free and separated from the rest of the bone but still approximately in place, apparently held in roughly the correct position by flesh.

This trash pit or gully was then covered by tan sandy clay until it had a level surface, and almost sterile soil was deposited above this as the lower component of stratum 2. Finally, a number of thin layers of ash, silt, charcoal, and some bone and other artifacts were collected on this surface. After this, most artifact deposition ceased, and stratum 1 formed as another layer of largely sterile clay.

\section{UNIT 14}

It was hoped that an area in the northern part of the state-owned property could be used as the visitors' center for the proposed work. To determine whether this area had any indications of a prior occupation, historic or prehistoric, a $1 \mathrm{~m}^{2}$ unit was placed in the approximate center for the proposed location. An earlier surface survey indicated that very little cultural material was to be found in this area, but a deep test was necessary to check this conclusion.

\section{Stratigraphy}

No stratigraphy was observed, other than a slight change in color and texture at ca. $30 \mathrm{~cm}$, probably indicating the bottom of the plow zone. The soil was a dark red-brown sandy clay. Four flakes of chert were found in the plow zone, but were considered to be plow fractures from the numerous large chert cobbles scattered through the soil. The excavation was taken $20 \mathrm{~cm}$ below the base of the plow zone with no further indications of cultural material.

\section{Observations}

No artifacts were found in the surface examination of the visitors' center area, and this, in conjunction with the complete lack of any cultural debris subsurface, indicates that there is no occupation on this hill, either aboriginal or historical. 
UNIT, 7.5

The location of the southwestern angle of the compound wall and the line of the eastern wall was known. Unit 15 was placed to establish the exact position of the south wall near the southeastern angle, and to examine the ground surfaces and stratigraphy outside the south wall.

\section{Stratigraphy}

Stratum 1 consisted of 2 to $4 \mathrm{~cm}$ of brown, sandy clay with a great deal of vegetal matter and some small rocks and pebbles.

Stratum 2 was a zone of wall debris with most of the large rock removed, as usual. The lower limit of the stratum was approximately level, while the top sloped upward to the remains of the wall. Larger rocks are found lower in the stratum. A large heap of debris and wall rubble lay along the inside of the wall line, and, in fact, is higher at its crest than the top of the surviving wall fragments.

Beneath the wall rubble was a thin lens of white mortar spilled or washed onto a rock-free soil surface. This strongly resembles the mortar between the stones of the wall, and probably represents a decay of the wall fabric or a spill of mortar during construction.

Stratum 3 below this thin white lens was a gray tan, with some charcoal and a few rocks and pebbles. Very few artifacts were seen in this stratum, and after ca. $5 \mathrm{~cm}$ it was decided to excavate only a $50 \mathrm{~cm}^{2}$ quadrant in the southwest corner. This was taken to a depth of $10 \mathrm{~cm}$ below the top of stratum 3 with only one chert flake found.

\section{Observations}

The top of stratum 3 was ground surface when the wall was constructed. Virtually no occupation debris was found, indicating that there is a good probability that no doorway or gateway was nearby. The unit resembles Unit 12 in general characteristics of artifact deposition, and again indicates that very little occupational activity took place outside the compound at any time during the active life of the site.

\section{THE ARTIFACTS}

For the purpose of interpreting the history of the site occupation, the artifacts recovered in the test excavations at Las Cabras can be divided into two basic time periods. Those which are commonly found on 18th century sites in the San Antonio River valley (see Schuetz 1969; Scurlock and Fox 1977; Greer 1967, Tunne11 1966; Gilmore 1974, 1975) are grouped together and considered to be of the Spanish occupation period. Artifacts which date to the late 19 th and early 20th centuries can with confidence be attributed to later, sporadic visits by local hunters, picnickers, and treasure hunters. The following brief descriptions summarize the various types of artifacts found and, wherever possible, show the basis for dating each type. 
The Spanish Occupation

The artifact assemblage found at this site contains objects which are also commonly found on all Spanish Colonial sites at San Antonio and Goliad. The groups represented include ceramics, glass, metal, and stone artifacts; some were manufactured in Mexico and brought to Texas by the Spaniards, some were made at local sites by the Indians or the Spanish citizens, and some were made locally using raw materials brought from Mexico. While it is generally possible to determine whether an object was made locally or in Mexico, insufficient information has as yet been obtained to be able to say exactly when many of the artifacts were made or by which group. However, as more sites are excavated, the dates when specific objects reached this area are gradually being determined.

\section{CERAMICS}

Ceramic sherds are generally the most numerous artifacts found in Spanish occupation sites. They are also the most useful for dating: deposits and features, since ceramics apparently were extremely sensitive to changes in style and technology, and reflect the needs and diet of the population. Thus, a particular variety would appear, become popular or readily available, and then in a relatively short time be replaced by a different variety. By studying these periods of popularity, it has been possible to establish a chronology for dating sites and structures within them. The shapes and sizes of vessels can also be used to infer information on what sort of diet the people had, particularly when combined with analysis of the animal bones found in the discarded refuse areas.

\section{Unglazed wares}

The most common ceramic types found on Spanish sites are fragments of unglazed bowls and jars. These can be divided into a locally made, hand-built ware commonly called Goliad ware (Fig. 8,k-q), and a wheel-made type which is more sophisticated both in construction and in firing technique. Goliad ware was fired over open campfires and shows the distinctive dark cores and variegated surface colors of such firing. The wheel-made pottery was evenly fired to a somewhat higher temperature, probably in a primitive kiln of some sort.

Goliad ware has a distinctive red brown to dark brown color and contains white flecks of crushed bone. Asphalt is occasionally used for decoration or crack mending. This ware was apparently an outgrowth of the pottery made by local prehistoric peoples. It continued in use through the Spanish Colonial period, with comparatively little change in construction or appearance. Of particular interest in this collection are two flat sherds which appear to be from comales or griddles, one of which bears fabric impressions (Fig. 8,m-n). Very few sherds of comales have been found on Texas sites, although mission inventories always 1 ist them. Probably the ones most commonly used were made of metal rather than ceramic.

Wheel-made wares tend to be pinkish $\tan$ to $\tan$ with a rather sandy paste. One variety has red-painted designs (Fig. $8, j$ ). A soft, low-fired variety, found frequently in 18th century sites in San Antonio and referred to here as Valero ware, may have been manufactured in San Antonio (Fox, Bass, and Hester 1976:67). Unglazed, burnished wares made in the tradition of pre-Columbian Mexican pottery are also represented on Spanish sites. These include a red ware with burnished 
Figure 8. Ceramics from Rancho de las Cabras.

\section{IMPORTED CERAMICS}

a. Huejotzingo blue-banded cup fragment, from Unit 11 , stratum 1 .

b. Red burnished ware bowl sherd from the surface outside the southeast corner.

c. Galera ware fragment from Unit 3, stratum 1.

d. French faience plate fragment, two shades of blue on white, from the surface outside the southeast corner.

e. Chinese porcelain, pale blue on white, from Unit 3 , stratum 4.

f. San Elizario majolica plate fragment, blue and brown on white, from the surface outside the southeast corner.

g. Monterey Polychrome majolica plate fragment, yellow, orange, brown and green on white, from Unit 8 , strata 1 and 2 .

h. Blue on white majolica bowl fragment from Unit 3 , stratum 1 .

i. Yellow-glazed, sandy paste heavy bowl fragment from Unit 11 , stratum 2 .

j. Unglazed, wheel-made jar with red painted design, found in Shovel Test 1.

$k, 1$. Sherds with asphaltum from Unit 11, stratum 3, and Shovel Test 1.

m. Comales fragment from Unit 11, stratum 4.

n. Fabric-impressed comales sherd from Unit 3, stratum 4.

o. Fragment of wide-mouthed $(\mathrm{ca} .7 \mathrm{~cm}$ ) jar from Shovel Test 1.

p. Handle fragment from Unit 3, stratum 3.

q. Portion of jar with constricted neck $(\mathrm{ca} .5 \mathrm{~cm})$ from Shovel Test 1 . 


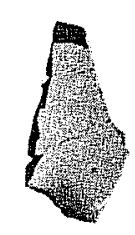

a

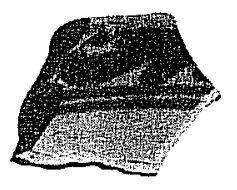

d

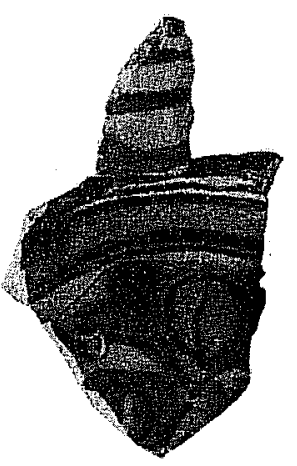

g

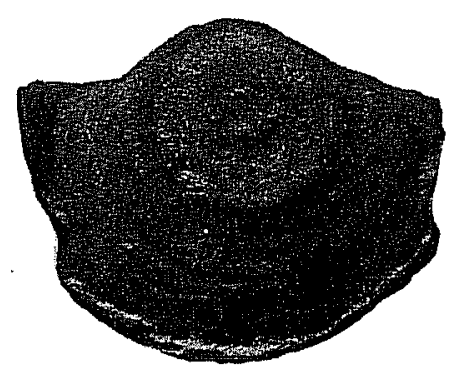

i

b

e
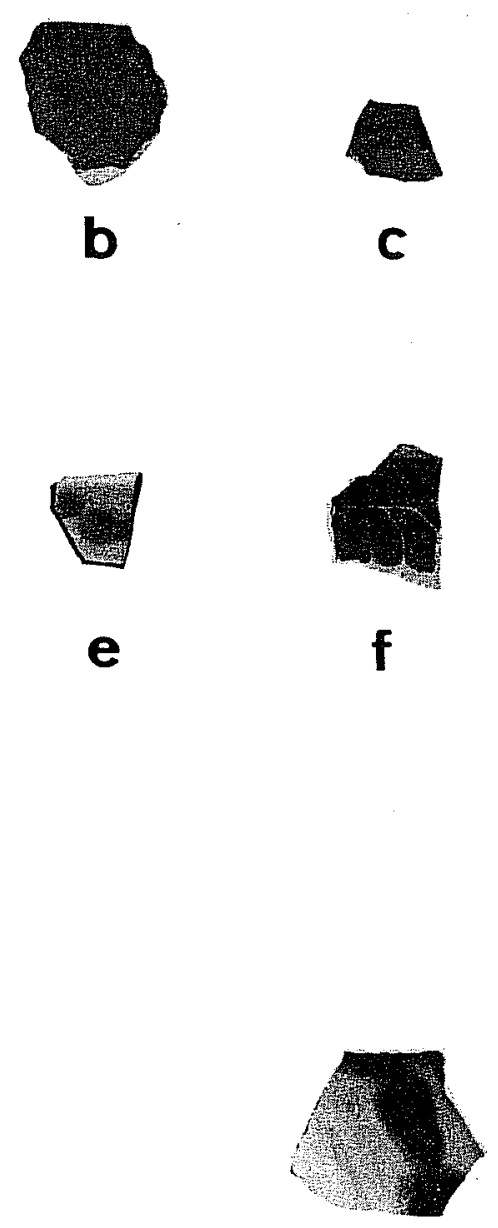

h

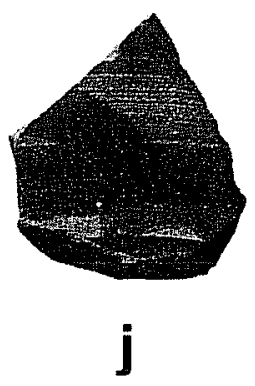

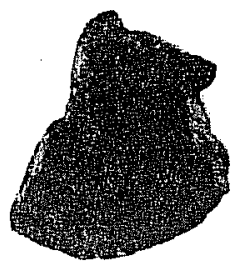

C

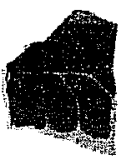

f

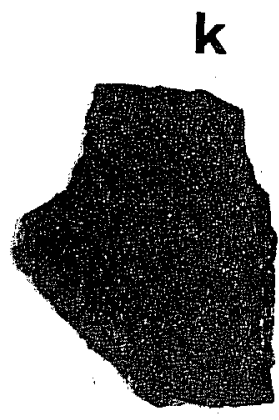

m
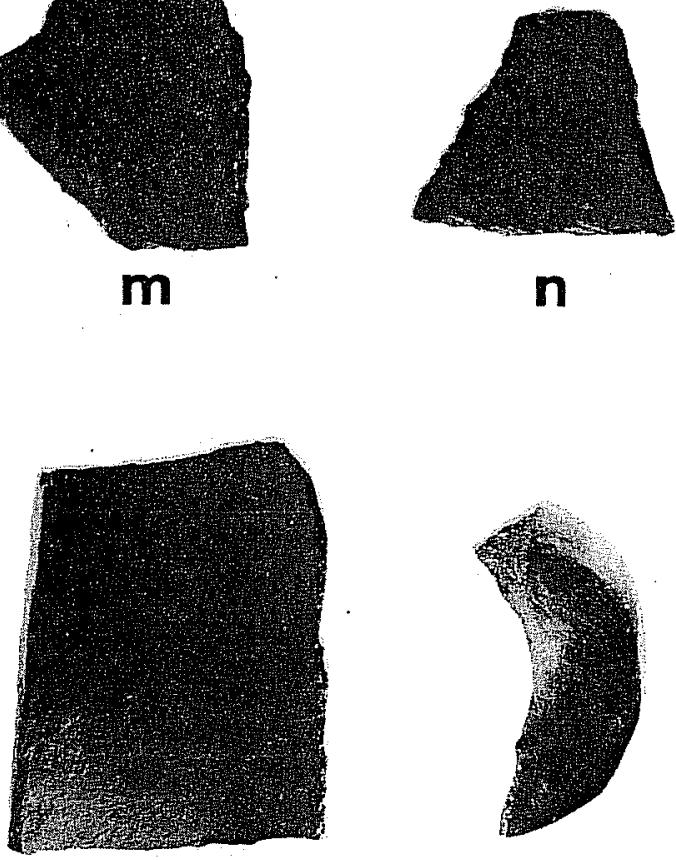

o

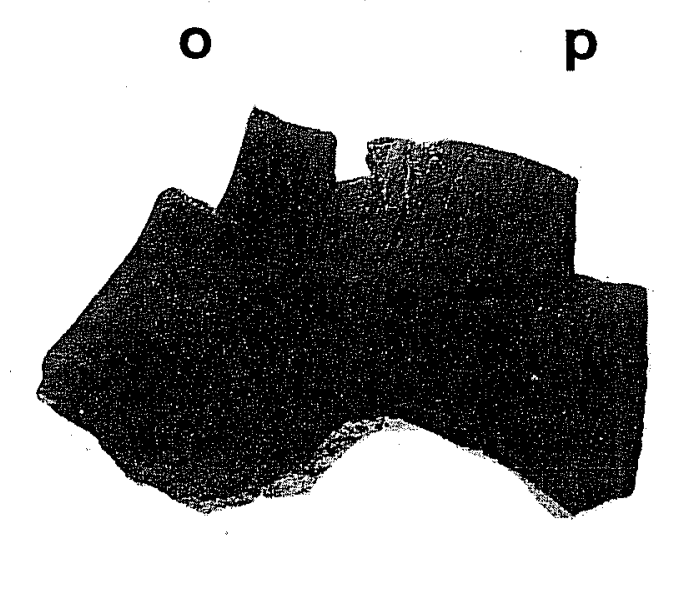

$q$

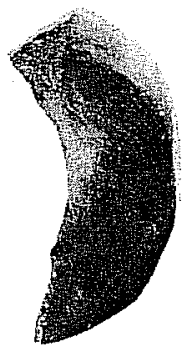

p

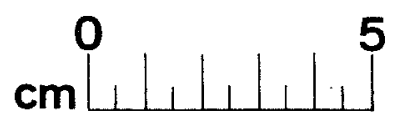


designs on a matte background (Fig. 8,b), probably from the Valley of Mexico, and a variety with tan paste, slipped with red, black, or polychrome decoration and highly burnished, which was made in Tonalá, Jalisco.

\section{Lead-glazed utility wares}

Vessels within this classification can be divided into two basic groups according to the content of the paste from which they are made and the technology used. Comparatively thick-walled wheel-made bowls and ollas with a sandy paste and a yellow or green glaze (Fig. 8,i) appear to be the second most common type of pottery used throughout the 18th century. Bowls occasionally have dark brown or green bands at the rim or center of the base. Since no indication has so far been found that glazing was practiced at the local settlements, it can be assumed that these vessels were imported from pottery making centers in Mexico.

Thinner-walled vessels with a finer paste, which contains little if any sand, appeared in Texas sometime soon after 1750 (Fox 1977a). Made primarily in the form of chocolate pots and bean pots, these vessels were mold-made in two parts and joined at the shoulder in a comparatively thick and sloppy seam. Decoration consists of dark brown and cream bands, dots, and floral designs, which occasionally have touches of green. Known by archaeologists as galera ware, this variety of ceramics apparently was popular from Texas to California during the last half of the 18th century. Only two sherds of this ware were found in the excavations (Fig. 8,c).

Other lead-glazed wares are generally present in small amounts, including thin, red ware bowls with a mahogany colored glaze attributed by Schuetz (1969:51) to Guadalajara, and sherds of black luster vessels probably originating in Michoacan (ibid.:52). Also found in most Texas sites are occasional sherds of heavy, whee1thrown olive jars, commonly used for shipping olive oil and wine on Spanish vessels around the world (Goggin 1964:253). These often have a white slip on the outside and a pale green to dark green glaze applied to the inside of the jar.

\section{Tin-enameled wares}

Commonly called majolica, this type of ware was made in Mexico, primarily in the city of Puebla. The ceramic type is often used for dating Spanish occupation sites because the style of decoration changed most perceptibly through the 17th to 19th centuries. While a number of discrete varieties have been established within the general categories described for this site, it is nearly impossible to sort a collection made up of such small fragments into anything more than color classifications.

A large percentage of the sample recovered consists of plain, white sherds, some of which are from undecorated portions of deep plates and cups. Two plain, undecorated cups or bowls are represented by rim fragments. Undecorated majolica was made throughout the 18th century (Lister and Lister 1974:30).

Another group of sherds contains blue decoration on a white background. Included in this category are probably pieces of Puebla Blue-on-White (Fig. 8,h) and bluebanded Huejotzingo (Fig. 8,a), which were popular throughout the 18th century (Lister and Lister 1976:134-136). 
A group of sherds which are white with blue and a touch of dark brown or black represent vessels of San Elizario (Fig. 8,f), popular during the last half of the 18th century (Gerald 1968:46), and appeared in San Antonio about 1760.

Sherds decorated in polychrome comprise the last and smallest majolica category present on the site. Of the total of 10 sherds, four from Unit 8 can be positively identified as Monterey Polychrome (Fig. 8,g), which May (Barnes and May 1972:36), dates from 1800 to. 1830 in California and Barnes (ibid.:12) reports was present in the Santa Cruz valley of Arizona from 1790 to 1830. The remaining six polychrome sherds were alt found on and directly above the occupation surface in Unit 11. They appear to represent types popular from 1750 to 1850.

One sherd of French faience, a tin-enameled ware similar to majolica, was found on the surface (Fig. 8,d). It is distinguished from majolica by the dul1 appearance of the enamel and a tendency of the glaze to flake or peel from the surface of the paste (Tunnell and Ambler 1967:35). This sherd bears a soft blue design on a white background, the paste is a yellowish tan. The design is similar to that on a platter excavated at a fort on the upper Mississippi which was occupied by the French from 1756 to 1765 (Brown 1975:94 and Fig. 3).

\section{Porcelain}

Another type of ceramic which is found in small quantities on Spanish sites is Chinese porcelain. Bowls of this ware were brought to Mexico from the Orient on Spanish galleons, made their way to Mexico City, and then came to the frontier on the supply trains or among the personal belongings of Spanish citizens. One sherd of blue and white porcelain was recovered from Unit 3 (Fig. 8,e).

\section{GLASS OBJECTS}

Glass containers in Spanish sites are generally limited to occasional wine bottles and small medicine bottles.. In this case, only a few fragments of glass were found which could be confidently identified as being of 18 th century manufacture. Two fragments of olive green wine bottles were recovered. One, part of the neck and rim of a bottle (Fig. 9,h), was identical in appearance and construction to one excavated at Presidio San Agustín de Ahumada (Tunne 11 and Ambler 1967:46 and Fig. 8). Presidio Ahumada was built in 1766 and abandoned in 1771 .

A sma11, thin aquamarine fragment is probably from a pharmaceutical or medicine bottle. This color was predominant in the 18th century (Nöe] Hume 1970:74), and a rim sherd from a similar-appearing bottle was recovered from 18th century deposits at Alamo Plaza (Fox, Bass, and Hester 1976:70 and Fig. 20)

GTass trade beads from Venice, Italy, are present on most Spanish sites. Sma11, colorful beads were given to the Indians to decorate their clothing and possessions or to string for necklaces. Jewelry containing glass sets was also 
brought to the frontier as gifts for the Indians. Three small, blue trade beads found in Units 2 and 3 are R. K. Harris' Type 48 (Harris and Harris 1967:144). Identical beads have been found at Mission Rosario (Gilmore 1975:131), at Mission San Juan Capistrano (Schuetz 1969:59), and at most other 18th century sites. Harris (ibid.) says of this type:

0ccurs in small numbers in most north Texas sites from 1700 to 1767 . Occurs in larger numbers between 1767 and about 1836 and then disappears.

A blue faceted glass inset (Fig. 9,c) meant to be mounted in a piece of jewelry was recovered from Unit 3 . It is similar to those found at other Spanish sites, but considerably larger than any so far recorded, being $14 \mathrm{~mm}$ across and $7 \mathrm{~mm}$ thick.

Black jet faceted rosary beads have been found at a number of Spanish sites. A complete rosary containing such beads was found with a burial dating ca. 1763 to 1785 at Mission San Juan Capistrano (Schuetz 1969:215 and P1ate 21). The bead found in this site is identical to those from San Juan and to a number of jet beads recovered at Mission Espiritu Santo and displayed in the museum there.

\section{METAL OBJECTS}

Artifacts made of metal are not numerous in 18th century sites. Perhaps the most common metal objects in these sites are fragments of copper or brass kettles and other containers. Metal was so precious on the frontier that these vessels were used until they wore out; they were then cut up and the pieces used for patching other vessels or for making other objects. Vessel fragments were found in Unit 2 and in direct contact with the plaster floor in Unit 4.

An interesting artifact made from scrap metal is an arrow point-shaped object found in Unit 2. (Fig. 9,f). A nearly identical point, but made of sheet iron, was found in excavations at Mission San Juan Capistrano (Schuetz 1969:P1ate 23G). R. K. Harris reported that several points of this type were found on the Brazos River at a site inhabited by the Towakoni tribe in the mid-19th century (ibid.: 49).

Another metal object found in a Spanish context is the copper furniture tack. This consists of a convex head of brass or copper with a shank of brass or iron. The head of one such tack was found in Unit 3 (Fig. 9,d).

Hardware fragments diagnostic of 18 th century Spanish furniture are rare in San Antonio valley sites. Especially interesting, therefore, is a small link or pin hinge (Fig. 9,e) from Unit 3. Although identical to those used to hang doors in Spanish structures, this one is the proper size to have been on a cabinet door or the lid of a storage chest.

Various types of ornamental buckles were used by the Spanish in the 18th century. An iron object from Unit 11 was probably a shoe buckle (Fig. 9,g). According to Nöel Hume (1970:86), shoe buckles were popular in the 18th century, and went out of use by about 1815 . 
Two lead musket balls (Fig. 9,a-b) were recovered from Unit 3 . They measure $1.5 \mathrm{~cm}$ in diameter, or .59 calibre. Although various sizes of musket balls have been found on Spanish sites little is known yet about the types of weapons used in the San Antonio area during this period.

\section{STONE OBJECTS}

The prehistoric tradition of working chert to make tools and weapons was apparently continued well into the 18th century in the San Antonio River Valley (Fox 1977b:16). Thin, bifacially worked chert artifacts made in the traditional forms (Fig. 9,0-p) are often present on Spanish sites. Fragments of two such bifaces were found in Unit 2, and the base of a punch or dril1 came from Unit 11 (Fig. 9,q).

A particular type of triangular projectile point seems to be found primarily on Spanish Colonial sites in Texas. These are commonly referred to as "mission" points (Fox 1979:26), or the tentative Guerrero type (Hester 1977). Three of these points were recovered (Fig. $9,1, m$ and $n$ ).

Two steeply bitted chert tools were found in Unit 3. They were made from thick flakes each showing considerable wear on one edge (Fig. 9, r-s).

An 18th century introduction to the local stone-working industry was the gun flint, necessary for firing the escopetas and pistols brought to the frontier by the Spanish. Some flints were imported from Europe, of which one example (Fig. 9,k) was found in Unit 2. Two others made of 7ocal chert (Fig. 9, $i-j$ ) were probably made on the site or in San Antonio. These were found in Units 3 and 11 .

A fragment of fine-grained limestone ca. $14 \mathrm{~cm}$ square (Unit 3 ) is highly polished on one face from use as a grinding stone, and in addition bears numerous shallow scratches similar to marks made by knife sharpening. This type of stone is not found in the area and would probably have been brought from San Antonio or elsewhere in the Hill Country. Similar multi-purpose tools are found on both prehistoric and historic sites in the general area.

\section{BUILDING MATERIALS}

In addition to stone and adobe structures, many Spanish sites also contained buildings of poles and clay, popularly called jacales. Fragments of burned clay daub which may have come from the walls of such buildings were found in Units 2, 3, and 12 .

Spanish buildings were often plastered. Fragments of wall plaster were recovered from several units. Lime for this plaster was probably burned on the site in a kiln similar to those at the San Antonio missions.

\section{FOOD REMAINS}

Large amounts of discarded animal bone were recovered from most of the excavation units. In addition, fragments of river mussel shells and occasional chicken egg shells were found. These remains are 1 isted in Table 2. 


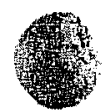

a

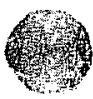

C

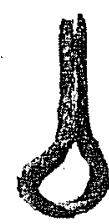

e

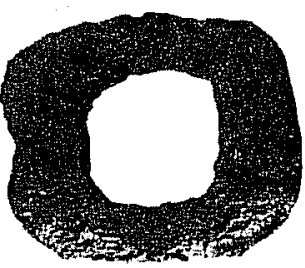

$\mathbf{g}$

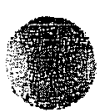

b

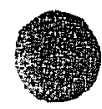

d

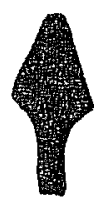

f

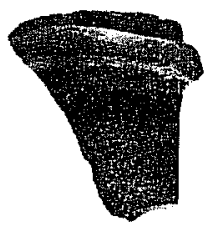

h
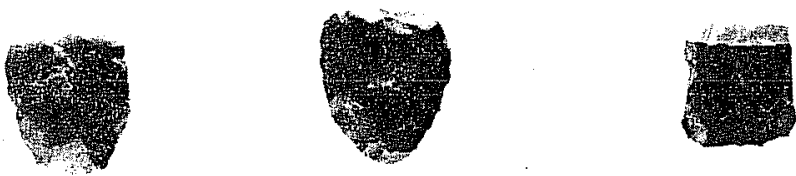

k
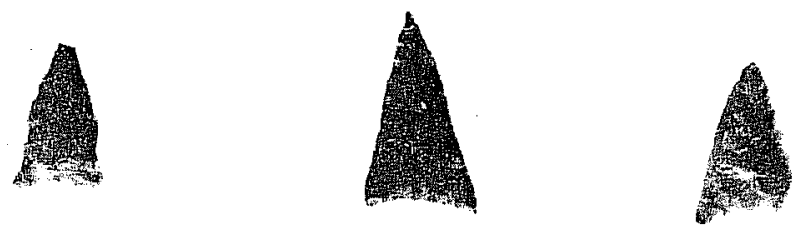

m

n
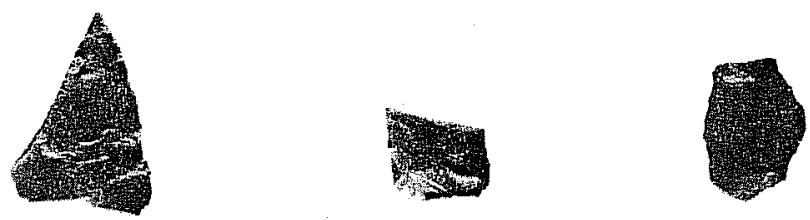

o

$\mathbf{p}$

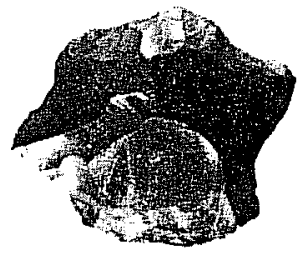

$\mathbf{r}$

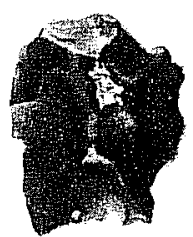

$\mathbf{s}$

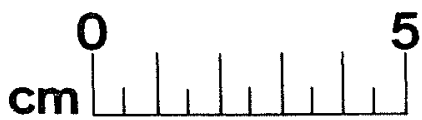

Figure 9. Artifacts from Rancho de las Cabras.

GLASS AND METAL ARTIFACTS

a,b. Lead musket balls, .59 calibre, from Unit 3, strata 1 and 2 .

c. Blue faceted glass inset from Unit 3 , stratum 2 .

d. Head of copper tack from Unit 3, stratum 2.

e. Iron link hinge from init 3 , stratum 1 .

f. Possible arrow point of copper from Unit 2, stratum 1 .

g. Iron buckle from Unit 11, stratum 2 .

h. 0live green wine bottle neck fragment, from Unit 12, stratum 1.

i. Locally made gun flint from Unit 11, stratum 2 .

j. Locally made gun flint from Unit 3, stratum 1 .

k. Imported gun flint of dark brown, translucent chert, from Unit 2, stratum 3 .
WORKED STONE

1. Arrow point from Unit 3, stratum 4.

m. Arrow point from Unit 3, stratum 1.

n. Arrow point from Shovel Test 1 .

o. Thin biface fragment from Unit 2 , stratum 1.

p. Thin biface fragment from Unit 2, stratum 1.

q. Punch or drill fragment from Unit 11 , stratum 1 .

r. Bifacially worked tool from Unit 3, stratum 1 .

s. Bifacially worked tool from Unit 3, stratum 2. 
FISH

Gar

Alligator Gar. Longnosed Gar

\section{REPTILES}

Turtles

Hardshe11 Turtle Softshel1 Turtle

Snakes

Moccas in

Rattlesnake

\section{BIRDS}

Chicken (domestic)

Turkey (wild)

\section{MAMMALS}

\section{Carnivores}

Hog-nosed skunk

Wolf

Cat

Rodents

Squirrel

Common cotton rat

Lagomorphs

Cottontail

Blacktailed Jackrabbit

Artiodactyles

Javalina

European pig

Cow

Sheep/goat
Lepisosteus sp.

Lepisosteus

Lepisasteus asseus
Testudines?

Trionix sp.

Agkriston sp. Crotalus $\mathrm{sp}$.

Gallus gallus

Meleagris gallopavo

Conepatus leuconotus

Canis $\mathrm{sp}$.

Felidae?

Sciurus sp.

Sigmodon hispidus

Sylvilagus cf flaridanus

Lepus californicus

Pecari angulatus

Sus scrofa

Bos sp.

Ovis sp./Capra sp.

Identifiable bone weight 19,340 grams

Unidentifiable bone weight 13,495 grams

Total bone weight $\quad 32,835$ grams 
19th and 20th Century Artifacts

Artifacts dating to the late 19th and early 20th centuries were found on the surface or in the first stratum of excavation units. These included one sherd of Ironstone chinaware popular in the late 19th century, a handle from a stoneware jug made at the Meyer pottery in Atascosa sometime between 1887 and 1940 (Greer and Black 1971:3,11), and two fragments of stone ware with a Bristol glaze which would have been made after 1900 (Georgeanna Greer, personal communication). Also recovered were fragments of late 19th and 20th century glass beverage bottles, cut and wire nails, tin can fragments, baling wire, and a number of cartridge cases dating from post-Civil war times to the recent past.

The Temporal Range of Site Occupation

The artifact sample indicates an occupation beginning at about the time San Elizario majolica was becoming popular in Texas, or ca. 1760. The occupation ended with the end of the period of popularity of Monterey Polychrome, which can be tentatively dated in Texas to $\mathrm{ca}$. 1820.

The sample of 19 th and 20th century artifacts indicates that no significant occupation occurred after about 1810.

\section{CONCLUSIONS}

Fourteen small test units constitute an extremely limited sample upon which to base any definite statements about the structural history or the cultural patterns of the Las Cabras site, but a general outline can be suggested.

\section{Structural History}

The occupation began with the construction of the compound in about 1760 . The walls of the compound and of three or four rooms along the north side were all apparently built in one continuous operation. The rooms along the north were probably flatroofed of lime and clay over log supports. Most of the compound was a hard-packed clay surface. One main entrance was through the north wall just west of the stone rooms, and there may have been another main entrance near the northeast angle. It is likely that torreon-type bastions were at the northwest and southeast angles. These were cylindrical structures less than 3-1/2 meters across, possibly made of a less durable material than the sandstone walls, and intended as a watch post and protected rifleman's position for firing along the outer faces of the walls, not as a cannon position.

Apparently the sandstone walls were left as bare rock throughout the site, including the surfaces within the north rooms, with the exception of the fourth room on the north, the chapel.

The chapel is so-called because popular legend says it once was exactly that. Although there is not direct evidence to support this attribution, the several peculiarities to be seen in the northeast angle make such a label reasonable, and it is accepted for now. 
The chapel and the entire northeast corner of the compound are enigmatic. There is some evidence to indicate that the chapel structure was built after the original plan of the compound. For example, there is a butt joint between the face of the north wall and the end of the chapel wall where it angles out from this face. Such a joint usually indicates that the two walls so joined were built at different times. A second peculiarity is the difference in thickness between the chapel walls from this butt joint on toward the north, which is ca. $64 \mathrm{~cm}$, and the thickness of the west wall of the chapel south of this joint, ca. $46 \mathrm{~cm}$.

There is an acceptable reason for the chapel to be at this odd angle relative to the rest of the compound: this allows it to face nearly due east, a desirable (but not necessary) characteristic for a church. There is no good reason for the chapel's west wall to turn at this angle as part of a secular structure, unless we assume an earlier pattern of original wall lines, corners, and a bastion or gateway to have been in this area. Such a possibility can be checked by

future work. For now we assume that the chapel is contemporary with at least the first years of the occupation of the compound.

A second feature of the compound which may not have been original is the room or rooms along the south wall, one of which is suggested by the plaster floor found in Unit 8. The presence of this floor with no clearly apparent walls dividing it from the rest of the compound argues for walls made of adobe or jacal, added after the main structure was built. Supporting this supposition is the lack of a thick bed of roofing adobe such as was apparently found in room 3 (Unit 4). The absence of this material argues for the presence of a grass roof such as was used on jacales, which did not have the strength to support a heavy clay roof. Such an added structure on the south may have been a utility building, but the plaster floor implies that it was a habitation. This may indicate that the population within the compound began to increase, requiring more housing, or that there was some class difference between the various components of the original occupants.

As the occupation of the site continued, Indian attacks along the San Antonio River Valley increased markedly. This increased threat may be the reason that the original northwest gateway was blocked by a masonry plug, probably narrowing it down to a doorway-sized opening. The work was done by people who understood the basics of stonework sufficiently to dig a footing trench for the plug, but who were far from accomplished stone masons. They built a very haphazard construction, but one which apparently served its purpose of reducing a dangerous opening.

At about the same time that the northwest gate was filled, a jacal was built inside the west wall near the northwest angle. A trench was dug from the stone wall outward into the compound, and tall posts were set into this trench close together. The gaps between the posts were probably filled with sticks, grass, or rocks, and the structure then covered with a coating of clay. No indication of a plaster floor was seen on the very small area of the interior of the structure uncovered by Unit 11. Outside of its north wal1, against the stone wall of the compound, a midden of trash, ashes and garbage from the kitchen began to pile up. Another trash dump, in a hole apparently dug for this purpose, was found outside a doorway remaining in the north wa11. The construction of this jacal, and possibly others in the same area, argues for a further increase in the population within the compound. 
Probably contemporary with the construction of the jacales on the west was some event involving the chape1, represented by a stratum of what appears to be mortar and plaster spill in Unit 10 (strata 6 and 7). This may signify the construction of the chapel, or a remodeling of it. Since the material found is finishing rather than destruction debris, which should have left large stone rubble scattered at this level, we may assume a continued existence for the chapel during this period. There is a buildup of multiple lenses of occupation debris above these strata, probably contemporary with the midden deposit in Unit 11, but without the quantities of ash and bone seen there.

This is followed by a massive deposition of animal manure, apparently all along the east and south areas of the compound. The presence of this material so near the front of the chapel in Unit 10 would indicate that the chapel was no longer in use. The plaster floor in the southeast angle was also buried under a thick bed of manure, indicating that certainly the room was no longer used as a residence, and may even have collapsed as a structure by this time.

The jacal built inside the west wall also apparently collapsed or was torn down, and this also may have happened before the manure deposition began. We will assume that the manure layer indicates a long-term use of the compound as a stock pen, and that this occurred after the effective abandonment of the site as a habitation. This would make the destruction of the jacal on the west wall and the abandonment and slow decay of the stone-walled rooms, the chapel on the north and the probably jacal on the south, roughly contemporary events. This, based on very limited artifactual evidence, probably occurred in ca. 1800.

After a period of use as a stockpen, the site entered a period of complete abandonment and decay. The evidence indicates that from perhaps 1800 until extensive stone robbing began in the early 1900s, virtually no artifacts of any kind were left on the site. Only sparse examples of small fires can be considered evidence for an occasional short-term camp within the ruins.

\section{Historical Context}

An examination of several historical sources supplies us with a general framework within which to place the preceding outline of the structural and occupational sequences of the site.

Ignacio Calvillo and his daughter, Maria are strongly linked to these ruins in local oral history. Weddle and Thonhoff $(1976: 148)$ have shown that Ignacio Calvillo was a rancher in the San Antonio River Valley as early as 1778, and is indicated as being the owner of the Rancho del Paso de las Mujeres by 1782. In 1791, this ranch was indicated as being still in use by Ignacio Calvillo. It is 1 isted as having been improved, but is without any residents at that date (Chabot 1937:168; Bexar Archives, Rol1 21, \#872, November 8, 1791).

In 1809, Calvillo sought full title to the ranch from Mission Espada (Ramsde11 1960). In 1814, Calvillo was killed by hostile Indians who attacked his ranch. "Ten to twelve people, including several women and children, managed to escape" and reach Mission Espada (Habig 1968:221). 
The Mexican government regranted the ranch to Calvillo's daughter Maria in 1828, because the original title had been lost (Ramsdel1 1960).

Information about the area before Ignacio Calvillo became connected with it is limited. In the inventory of Espada Mission made in 1762, the mission ranch is said to have "a good stone house where the cowboys and shepherds could live comfortably" (Habig 1968:215). Father Gaspar. Jose Solis mentions passing through "el Rancho de las Cabras". in 1768, but gives no details other than that it was on the west side of the San Antonio River (Habig n.d.:3).

Father Juan Augustin Morfi mentioned that Rancho de las Cabras had 26 residents in about 1777, and $\mathrm{Fr}$. Mariano Vasconcelos narrates an incident in 1781, where Felipe and Anastacio. Lopez were killed by Indians after having left the Rancho de las Cabras (Habig n.d.:5,6; Narvais 1977:17).

Complications in the historical picture arose with the appearance of evidence that Las Cabras was in operation. at the same time that Calvillo. was operating Rancho del Paso de las Mujeres (Bexar Archives, Rol1 18, \#005, January 8, 1787). Fina11y, the Rancho de las Cabras, immediately south of Calvillo property, was granted to Manuel Barrera in 1833. Since the structure we have been investigating is not on Barrera's Las Cabras property, does this mean that it is not the Rancho de. las Cabras?

There is little reason to doubt that the land eventually granted to Calvillo and later to his daughter belonged to Mission Espada, nor that the site discussed in this report is old enough to have been. referred to as "a good stone: house" in 1762. It is likely that the problem is only one of a lack of knowledge and understanding. The ranch of a mission was the land, not a building on that land, and it is 1 ikely that the entire ranch tract. of Espada was called Rancho de las Cabras. When Calvillo acquired a portion of the ranch in ca. 1780, he may have named this property el Paso de las. Mujeres, and at the same time have had the ancient mission of Las Cabras on the same property. while the remainder of the ranch to the south continued to be called the Rancho,de. las Cabras. The questions to be investigated, then, are as follows: Exactly what system of buildings were built in the tract of the Espada Ranch, and was any specific structure named Rancho de las Cabras? Can the Calvillo Rancho be identified with the structure under investigation, or shown explicity to have been a different place?

Life in the Compound

A few general statements can be made about the people who lived in this structure, and how they lived.

One of the most pronounced contrasts of the site is that between the large expenditure of time and money required to build such a structure, and the obvious lack of wealth of its occupants, so far as we know them from the archaeological evidence. The most likely deduction which can be made from this is that the person or persons who paid for this establishment did not live here. A well-to-do family could have lived on the site and had their. household trash and garbage dumped somewhere other than any of the areas we sampled, but this is unlikely. 
Some indication of what animals were being eaten can be seen in the faunal inventory. Not only were cattle and sheep being used, but fish and turtles from the river, squirrels and rabbits from the surrounding wooded and grassy areas, several varieties of birds including domestic chicken, and apparentiy anything else that came to hand were also meat for the pot. No indication of vegetal contributions to the diet were seen in the archaeology. The fragment of a possible comal does, however, hint at the baking of tortillas from corn meal, among other uses.

Apparently a major part of the food was prepared largely in the form of stews and soups in pots and bowls exposed directly to the fire, and eaten from bowls and deep plates. Tortillas probably served as one of the main eating utensils along with fingers.

One noticeable lack in the artifact sample is that of galera ware. Two explanations are likely: either the time of the occupation is wrong, or there are cultural-economic factors at work reducing the amount which does occur to a very low level. Two sherds were found in the top two strata of Unit 3, indicating that the ceramic was in use on the site, and all indications of the period of use of galera say that it began to appear in Texas about 1750, or a little later and continued through the century and well into the nineteenth century. We would have expected at least ten times as high a count of sherds of this material. Apparently the lack is significant, and would seem to be culturaliy or economically derived. It is suggested that galera is associated with a group of activities peculiar to a moderately well-to-do economic status, and that the lack here may be caused by a set of food preparation activities associated with a relatively low economic status. If future excavation reveals a continued low level of galera, or shows that it appears only in certain contexts on the site, such a conjecture may be tested against the pattern of appearance, or lack of it.

This structure must have served as the headquarters of a ranch. This means that all who lived here are concerned, directly or indirectly, with the raising of 1 ivestock. The yearly cycles of 1 ife were geared to the movements and habits of the herds in the area. The cattle were effectively feral; that is, they were wild animals who belonged to a given ranch, in most cases, only because they happened to be on the land of that ranch at the time of roundup. Branding was relatively rare.

Cattle were worth little in themselves. Certainly the people of this ranch did not need thousands of cattle for their own use. Cattle would be considered as wealth only insofar as they could be exchanged for other necessities or luxuries. The existence of the ranch indicates that there was a demand for the cattle. This means that the routines of herding, protection, and branding were all predominantly directed towards getting the cattle to their market. Such a process would require that added to the list of activities must be the trail drive to markets in northern Mexico or Louisiana, or the rendering of cattle into tallow and hides and the shipment of these goods to those areas.

These considerations show that the people who lived in Las Cabras were almost certainly in close contact with 1 ife in San Antonio, the rest of Texas, and northern Mexico, and should not be considered as a tiny rural village outside of the main currents of the culture of Frontier Texas. 


\section{RECOMMENDATIONS}

The next phase of excavations should be directed towards a more detailed understanding of the structural history and its associated material culture. To accomplish this, several area excavations and several further testing operations should be conducted.

One area excavation should be laid out on the jacal located within the west wall. of the compound. This should be designed to locate the entire wall perimeter of the structure, and to accurately plot a11 features and artifact concentrations within and around the structure.

A second area of excavation should be conducted along both sides of the north wall in the area of the blocked northwest gate. This would locate the other edge of the gate and determine if there was a smaller opening left in this area when the blocking wall was constructed. In association with this, the suspected trash pit outside the northwest gate should be excavated, with special attention paid to the sequence of artifact deposition. If the trash pit is fairly extensive, a very good artifact sample of the material culture from most of the periods of occupation should result.

Testing should be done on one or both suspected bastions to determine their size, construction, and what sort of problems might accompany their excavation and preservation. The southeastern angle should receive further tests to determine whether the walls of a structure surround the plaster floor in this area. Other units should test the possibility that a wall may have originally extended from the present west wall of the chapel to the east wall of the compound, and the possibility that a wall and bastion were located on the northeastern angle.

No further excavation within the stone-walled rooms along the north side or within the chapel are recommended until arrangements are made to stabilize the walls, floors, and any wall plaster that may be found. The possible trash pit seen in Unit 13 should be left until a later season of excavation as should the depression in Unit 5.

In conjunction with these excavations, extensive historical research should be carried out to define the relationship between the site, the Mission Espada, and the secular ranch of Ignacio Calvillo. Considerable information concerning these ranches is readily available in the Bexar Archives, and other details are probably available in the 01d Spanish Missions Library, in other archival collections in Austin, and elsewhere. Without this research, the true nature of the site will be only conjecture. Much of the possible understanding of this ranch and the people who lived on it would be produced by a coordinated ethnohistorical and archaeological research program, operating simultaneously. Such a research program cannot be recommended too strongly.

To aid in future excavation and to prevent further damage to the structure, a11 brush should be killed and removed from the compound walls and interior. The site should be fenced to prevent cattle from climbing over the walls, as they do presently.

The areas suggested for an entrance road and visitors' center appear to be without cultural resources, and are probably safe for such construction. Care should be taken as this work is carried out, so that if a deeply buried site should be uncovered, mitigative work can be done. 
REFERENCES CITED

Barnes, M. R. and R. V. May

1972 Mexican Majolica in Northern New Spain. Pacific Coast Archaeological Society Occasional Paper, 2.

Bexar Archives

$1731-$

1836 University of Texas At Austin, Eugene C. Barker Archives Microfilm.

Brown, M.

1975 Preliminary Investigations at Fort de Chartres. In Stanley Smith, editor, The conference on Historic Site Archaeology. Institute of Archeology and Anthropology, University of South Carolina. Papers 1973 , Volume 8.

Chabot, F. C.

1937 With the Makers of San Antonio. Artes Graficas; San Antonio.

Fox, A. A.

1977a Ceramic Comparisons. The Archaeology and Ethnohistory of the Gateway Area, Middle Rio Grande of Texas. Report to National Endowment for the Humanities. Assembled by R. E. W. Adams. The University of Texas at San Antonio.

1977b The Archaeology and History of the Spanish Governor's Palace Park. Center for Archaeological Research, The University of Texas at San Antonio, Archaeological Survey Report 31.

Fox, A. A., F. A. Bass, Jr. and T. R. Hester

1976 The Archaeology and History of Alamo Plaza. Center for Archaeological Research, The University of Texas at San Antonio, Archaeological Survey Report 16.

Fox, D. E.

1979 The Lithic Artifacts of Indians at the Spanish Colonial Missions, San Antonio. Center for Archaeological Research, The University of Texas at San Antonio, Special Report 8.

Gerald, R. E.

1968 Spanish Presidios of the Late Eighteenth Century in Northern New Spain. Museum of New Mexico Research Record 7. 
Gilmore, $K$.

1974 Mission Rosario, Archaeological Investigations 1973. Texas Parks and Wildlife Department, Historic Sites and Restoration Branch. Archaeological Report 14, Part 1.

1975 Mission Rosario, Archaeological Investigations 1974. Texas Parks and Wildlife Department, Historic Sites and Restoration Branch. Archaeological Report 14, Part 2.

Goggin, J. M.

1964 The Spanish 0live Jar. Indian and Spanish selected Writings. University of Miami Press, Coral Gables, Florida.

Greer, J. W.

1967 A Description of the Stratigraphy, Features and Artifacts from an Archaeological Excavation at the Alamo. State Building Commission Archaeological Program, 3.

Greer, G. H. and H. Black

1971 The Meyer Family: Master Potters of Texas. Trinity University Press, San Antonio.

Habig, M. A.

1968 The Alamo Chain of Missions, A History of San Antonios' Five old Missions. Franciscan Herald Press, Chicago.

n.d. A Review of Mission de las Cabras, Wilson County, Texas. Feasibility Report, manuscript on file at Texas Parks and Wildlife, Austin.

Harris, R. K. and I. M. Harris

1967 Trade Beads. Projectile Points, and Knives. In A Pilot Study of Wichita Indian Archaeology and Ethnohistory. Assembled by R. B. Bell, E. B. Jelks, W. W. Newcomb. Report to the National Science Foundation, Grant GS-964.

Hester, T. R.

1977 The Material Cultural at Missions San Juan Bautista and San Bernardo. Paper presented at Symposium at the Society for Historical Archaeology meeting, San Antonio, January 1978.

Lister, F. C. and R. H. Lister.

1974 Majolica in Colonial Spanish America. Historical Archaeology $8: 17-52$. 
1976 Distribution of Mexican Majolica along the Northern Borderlands. In Collected Papers in Honor of Marjorie Ferguson Lambert, Papers of the Archaeological Society of New Mexico 3:113-140.

Narvais, Fr. Cosme Logano (Fr. Mariano Antonio de Vasconcelos)

1977 Journal of a Texas Missionary, 1767-1802. 01d Spanish Missions Historical Research Library, Documentary Series 3. San Antonio.

Nöe1 Hume, I.

1970 A Guide to Artifacts of Colonial America. Alfred Knopf, New York. Ramsde11, C.

1960 'Mission de las Cabras' Built by Early Spanish Priests Near Floresville; The Mission of the Goats. Floresville ChronicleJournal, Friday, September 16, 1960. Floresville, Texas.

Șchuetz, M. K.

1969 The History and Archaeology of Mission San Juan Capistrano, San Antonio, Texas, Vol. II (of 2 vols.). State Building Commission Archaeological Program, Report 11, Austin.

Scurlock, D. and D. E. Fox

1977 An Archaeological Investigation of Mission Concepcion, San Antonio, Texas. Office of the State Archaeologist Report 28.

Tunnel1, C. D.

1966 A Description of Enameled Earthenware from an Archaeologica.] Excavation at Mission San Antonio de Valero (The Alamo).' State Building Commission Archaeological Program Report 2, Austin.

Tunne11, C. D. and J. R. Ambler

1967 Archaeological Excavations at Presidio San Agustín de Ahumada. State Building Commission Archaeological Program, Report 6, Austin.

Weddle, R. S. and R. H. Thonhoff

1976 Drama and Conflict, The Texas Sage of 1776. Madrona Press, Austin. 


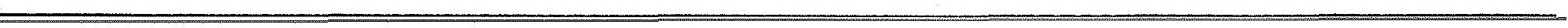


